\title{
Synthesis and Antitumor Activity of Mechercharmycin A Analogs
}

Delia Hernández, ${ }^{a}$ Marta Altuna, ${ }^{a}$ Carmen Cuevas, ${ }^{b}$ Rosa Aligué,${ }^{c}$ Fernando Albericio, $,{ }^{a}: * *$ Mercedes Álvarez, ${ }^{a}{ }^{*}{ }^{*}$

a: Institute for Research in Biomedicine, Barcelona Science Park-University of Barcelona, Baldiri Reixac 10, E-08028 Barcelona, Spain; a: CIBER-BBN, Networking Centre on Bioengineering, Biomaterials and Nanomedicine, Barcelona Science Park, Baldiri Reixac 10, E-08028 Barcelona, Spain; b: Pharma Mar, S.A., Avda de los Reyes 1, E- 28770 Colmenar Viejo, Madrid, Spain; c: Department of Cell Biology, Faculty of Medicine, University of Barcelona, Casanova 143, E-08036 Barcelona, Spain fernando.albericio@irbbarcelona.org, mercedes.alvarez@irbbarcelona.org

\footnotetext{
${ }^{\ddagger}$ Department of Organic Chemistry, University of Barcelona, E-08028 Barcelona

$\S$ Laboratory of Organic Chemistry, Faculty of Pharmacy, University of Barcelona, E08028 Barcelona

* Fernando Albericio, Tel: (+34) 93403 7088; Mercedes Álvarez, Tel: (+34) 93403 7086; Fax: (+34) 934037126
}

Abreviations: A-549, Human lung cancer cells; DAST, Diethylamino sulfur trifluoride; DBU, 1,8-Diazabicyclo[5.4.0]undec-7-ene; DIEA, Diisopropylethylamine; DMAP, 4Dimethylaminopyridine; DMF, Dimethylformamide; DMSO, Dimethylsulfoxide; EDC.HCl, 1-(3-Dimethylaminopropyl)-3-ethylcarbodiimide hydrochloride); FAMDEVD-FMK, Carboxyfluorescein derivative of fluoromethyl ketone; HOBt, 1Hydroxybenzotriazole; HT-29, Human colon cancer cells; HTB, Human colorectal adenocarcinoma cell line; L.R, Lawesson's reagent; MsCl, Mesyl chloride, NSCL, Nonsmall cell lung; MDA-MB-231, Human breast adenocarcinoma cancer cells; PBS, Phosphate buffered saline; PEG, Poly(ethylene glycol); TEA, Triethyl amine; TFA, Trifluoroacetic acid; THF, Tetrahydrofurane. 
Title running head: Synthesis and Antitumor Activity of a Cyclic Thiopeptide Analogs

\title{
RECEIVED DATE (to be automatically inserted after your manuscript is accepted if required
}

\begin{abstract}
Several analogs of the cytotoxic thiopeptide IB-01211 or Mechercharmycin A (1) have been synthetized. The cytotoxicity of $\mathbf{1}$ and the synthetized analogs was evaluated against a panel of three human tumor cell lines. Thiopeptide $\mathbf{1}$ and the most active derivatives, $\mathbf{2}$ and $\mathbf{3 c}$, were chosen for further studies like effects on cell cycle progression and induction of apoptosis. Interestingly, the inhibition of cell division and activation of a programmed cell death by apoptosis was detected.
\end{abstract}

Key words: azoles, peptides, conjugation, cytotoxicity

\section{INTRODUCTION}

Natural products are a rich source for drug discovery and are challenging synthetic targets; hence, they often inspire new synthetic methods. ${ }^{1}$ Thiazoles and oxazoles, as well as their reduced variants, are common structural features of many biologically important natural products. ${ }^{2}$ Only few concatenated azoles containing substituents on the azole rings have been described. These comprise the methylated bisoxazoles (-)-muscoride $\mathrm{A}^{3}$ and leucamide $\mathrm{A},{ }^{4}$ the cyclic octa-azole telomestatin, ${ }^{5}$ which features two oxazole rings with methyl substituents at position 5 and finally, the diazonamides, ${ }^{6}$ which have a complex structure containing a bis-oxazole. IB-01211 or mechercharmycin A (1) is a cyclic thiopeptide ${ }^{7}$ containing a phenyl-penta-azole system, a D-allo-Ile-L-Val dipeptide, 
and an exocyclic methylidene. The synthesis of $\mathbf{1}$ was recently described by our group. ${ }^{8}$ Thiopeptide $\mathbf{1}$ is closely related in structure to the potent telomerase inhibitor telomestatin $^{5}$ and YM-216391. ${ }^{9}$

We sought to prepare analogs of 1 with improved solubility and activity. The first structural modifications comprised substitution on the penta-azole system and modifications of the exocyclic methylidene (Figure 1). We envisaged that introduction of one $(\mathbf{1 a}, \mathbf{b})$ or two (1c) methyl groups could increase the solubility of the parent compound and allow a conformational change. The second variation consisted of modifying the exocyclic double bond via elimination (2) or conjugation of the hydrate form $\mathbf{3}$ with acids, PEG residues or amino acids (3a-f).

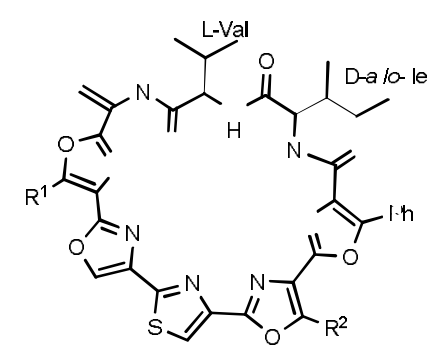

$1 R^{1}=R^{2}=H$ i) SU STITUTIONONT E

ENTA-AZOLESYSTEM

1a $\mathrm{R}^{1}=\mathrm{Me} ; \mathrm{R}^{2}=\mathrm{H}$

1b $\mathrm{R}^{1}=\mathrm{H}_{;} \mathrm{R}^{2}=\mathrm{Me}$

1c $\mathrm{R}^{1}=\mathrm{R}^{2}=\mathrm{Me}$

i) ODIFCATIONS OF T EE OCYCLIC METHYLID NE

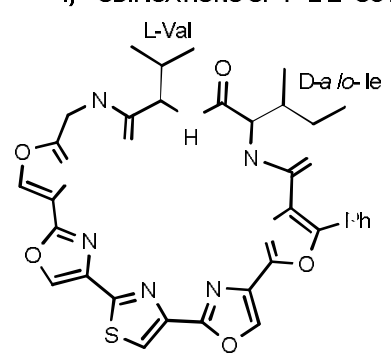

2

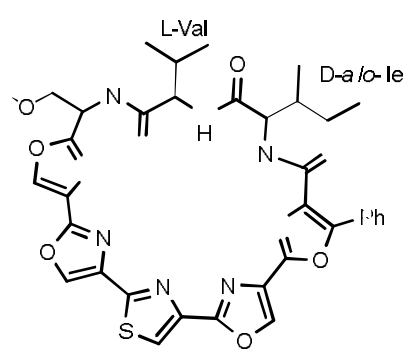

$3 \mathrm{R}=\mathrm{H}$

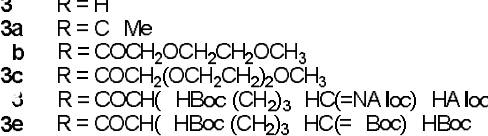

if $\mathrm{R}=\mathrm{COCH}\left(\mathrm{H}_{2}\left(\mathrm{CH}_{2}\right)_{3} \mathrm{HC}(=\mathrm{H}) \mathrm{H}_{2}\right.$

Figure 1. Structures of thiopeptide 1 and analogs 1a-c, 2 and 3a-f 


\section{RESULTS AND DISCUSSION}

\section{Chemistry}

Compounds 1a-c, 2, and 3a-f were synthesized using basically the same strategy that we described for the total synthesis of $\mathbf{1}^{8 \mathrm{a}}$ This is a convergent method based on macrocyclization with simultaneous formation of the thiazole ring from a peptideheterocycle. Having previously reported the difficulty of handling the alcohol $3{ }^{8}$ we used different conditions for the macrocyclization of the intermediates leading to $\mathbf{2}$ and the esters 3a-e than for those leading to 1a-c, which feature an exocyclic methylidene. Thus, whereas 3a-e were all prepared from $\mathbf{3}$ via experimental conditions that avoid dehydration, 1a-c were obtained through concomitant macrocyclization and formation of the thiazole and the double bond.

The syntheses were built around three synthetic intermediates: the bis-oxazoles 4a-c, the phenyl-bis-oxazoles $\mathbf{5 a}$ and $\mathbf{5 b}$, and the dipeptide $\mathbf{6}$ (Scheme 1). Compounds $\mathbf{4 a}$ and $\mathbf{5 a}$ have previously been synthesized ${ }^{8}$ by a process based on cyclization of Ser and $\mathrm{Ph}$-Ser peptides to give an oxazoline, followed by further oxidation to afford the oxazole. This method was used to prepare oxazoles $\mathbf{4 b}, \mathbf{4 c}$ and $\mathbf{5 b}$, using Gly- and Thr-containing peptides, as well as Ser and $\mathrm{Ph}-\mathrm{Ser}$, as starting materials (see Experimental Details). The peptide-heterocycles $\mathbf{7 a}$ and $\mathbf{7 b}$ were obtained in excellent yields from the peptide $\mathbf{6}$ and compounds 5a, 5b, respectively, using EDC.HCl (1-(3-dimethylaminopropyl)-3ethylcarbodiimide hydrochloride) and HOBt (1-hydroxybenzotriazole) as coupling agents. The tetra-oxazole-peptides 9 were obtained from the corresponding free acid of $7^{10}$ and the appropriate amine $\mathbf{8}$ under the conditions described above. Compounds 9 a-e feature three key functional groups: a thioamide, an acetal-protected $\alpha$-bromoketone, and 
a tert-butoxymethyl group $\left(\mathrm{R}=\mathrm{CH}_{2} \mathrm{O} t \mathrm{Bu}\right.$ for 9a-d). Simultaneous elimination of the Ot $\mathrm{Bu}$ protecting group and the dimethylacetal of $\mathbf{9}$ using formic acid under reflux afforded the free alcohol plus the $\alpha$-bromoketone, which was ready for macrocyclization via thiazole formation. Macrocyclization was achieved by refluxing a dilute ethanolic solution of the crude material for $48 \mathrm{~h} .{ }^{11}$ For 1a-c (Scheme 1, left), this reaction was followed by dehydration of the crude material using mesyl chloride and triethyl amine (TEA) at low temperature. The last step after the macrocyclization was avoided when 9e was used to give compound 2. Using 9a this route gave, after deprotection and macrocyclization, alcohol 3, which was directly acylated to give 3a-e. Acetate 3a was obtained using acetic anhydride in THF at room temperature. Compounds $\mathbf{3 b}$-e were prepared by reaction of the appropriate acid with the alcohol 3 using EDC.HCl and 4dimethylaminopyridine (DMAP) as condensation agents. The protection initially used for $\operatorname{Arg}$ was $N^{\alpha}$-Boc, bis- $N^{\gamma, \gamma^{\prime}}$-Alloc, which allowed isolation of $\mathbf{3 d}$ in $16 \%$ yield under the conditions described above. Elimination ${ }^{12}$ of the Alloc protecting group gave a crude product in which $N^{\alpha}$-Boc-3f only corresponded to 3\% (as detected by HPLC-MS). The deprotection gave better yield using tri-Boc-protected Arg. Simultaneous elimination of the three protecting groups of $\mathbf{3 e}$ using trifluoroacetic acid (TFA) diluted in $\mathrm{CH}_{2} \mathrm{Cl}_{2}$ allowed the isolation with a $17 \%$ yield of purified $\mathbf{3 f}$. 


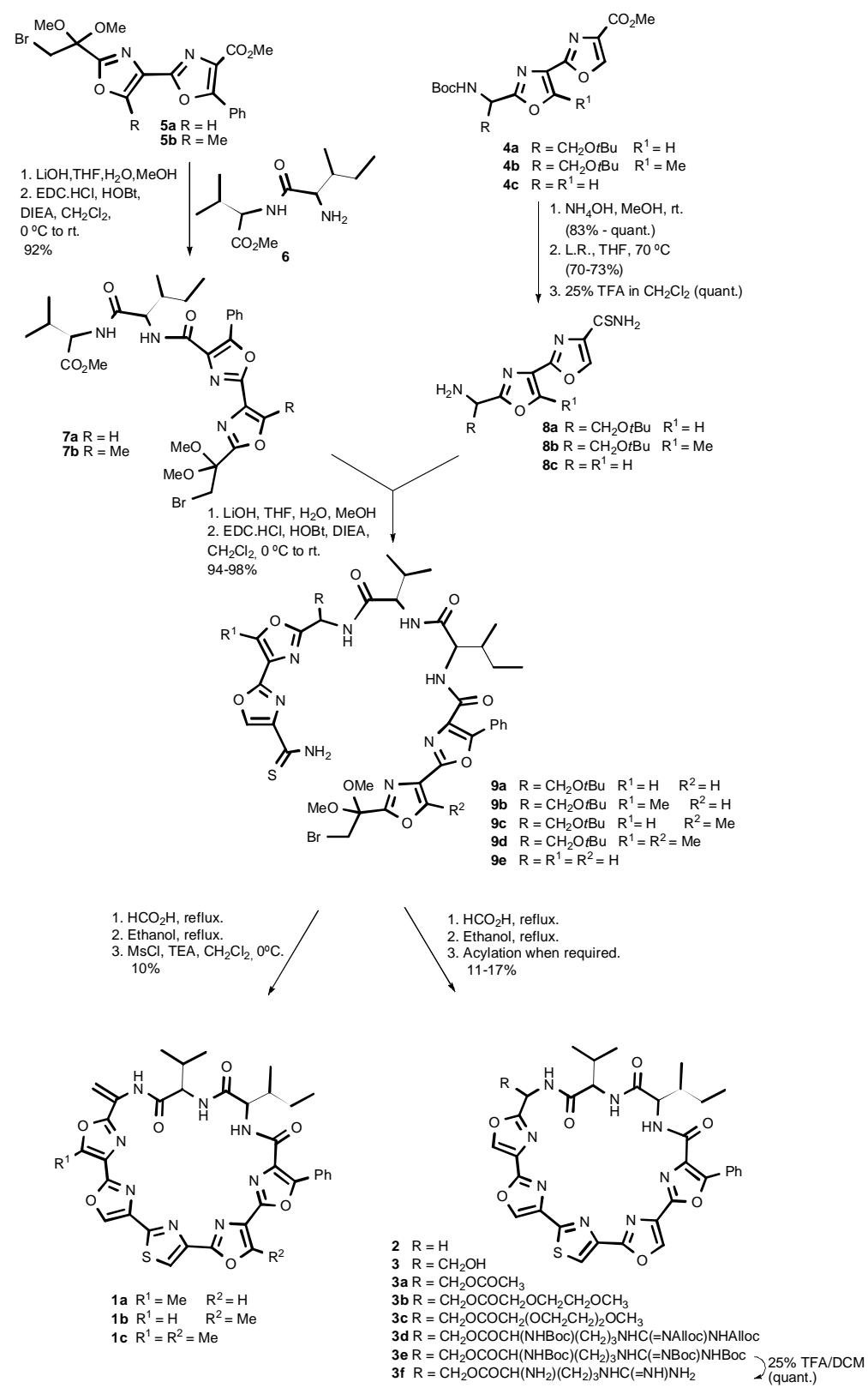

\section{Scheme 1 Synthesis of thiopeptide 1 analogs}

\section{BIOLOGICAL RESULTS}

The cytotoxicity of the thiopeptide $\mathbf{1}$ analogs was evaluated against a panel of three human tumor cell lines: A-549 lung carcinoma NSCL, HT-29 colon carcinoma, and MDA-MB-231 breast adenocarcinoma. 
A conventional colorimetric assay was used to estimate values of $\mathrm{GI}_{50}$ (defined here as the drug concentration which causes $50 \%$ of cell growth inhibition after 72 hours of continuous exposure to the test molecule). Thiopeptide $\mathbf{1}$ was included for comparison. The results are shown in Table 1.

Table 1 In vitro cytotoxicity of 1 and its open-chain and cyclic peptide analogs

\begin{tabular}{|c|c|c|c|}
\hline \multirow{2}{*}{ Compound } & \multicolumn{3}{|c|}{ Cytotoxicity $\left(\mathrm{GI}_{50} \mu \mathrm{M}\right)$} \\
\hline & A-549 & HT-29 & MDA-MB-231 \\
\hline$\underline{1}$ & 0.03 & 0.04 & 0.09 \\
\hline $1 \mathbf{a}$ & 1.66 & 2.49 & 2.91 \\
\hline $1 b$ & 0.54 & 0.63 & 1.02 \\
\hline 1c & 0.31 & 0.36 & 0.70 \\
\hline 2 & 0.17 & 0.12 & 0.10 \\
\hline $\mathbf{3 a}$ & 4.68 & 4.94 & 4.03 \\
\hline $\mathbf{3 b}$ & 0.89 & 1.31 & 1.16 \\
\hline $3 c$ & 0.12 & 0.13 & 0.13 \\
\hline $3 f$ & n.a. & n.a. & n.a. \\
\hline $9 \mathbf{a}$ & n.a. & n.a. & n.a. \\
\hline $9 b$ & n.a. & n.a. & n.a. \\
\hline $9 c$ & 4.99 & n.a. & 4.46 \\
\hline 9d & n.a. & n.a. & n.a. \\
\hline $9 e$ & n.a. & n.a. & n.a. \\
\hline
\end{tabular}

n.a.: not active at $10 \mu \mathrm{g} / \mathrm{mL}$

All the cyclic analogs, except $\mathbf{3 f}$, are active against human tumor cell lines, but to a lesser extend compared to $\mathbf{1}$. Introduction of one or two methyl-substituents (1a-c) diminishes the $\mathrm{GI}_{50}$ by one order of magnitude for $\mathbf{1 b}$ (lines A-549 and HT-29) and 1c (all three lines), and by two orders of magnitude for 1a (all three lines) and 1b (MDA-MB-231). The greatest cytotoxicity is found in derivatives in which the exocyclic double bond was eliminated (2) or substituted by a PEG-carboxymethyl (3b and 3c). Acetate derivative 3a maintains a modest growth inhibition at $\mu \mathrm{M}$ concentrations in the three lines; however, 
acylation with an Arg residue leads to total loss of activity. Interestingly, substitution of the acetyl residue by a methoxyethoxyacetyl in $\mathbf{3 b}$ increases cytotoxicity to A-549; likewise, the longer polyetheracetyl of $\mathbf{3 c}$ produces the same effect in all three tumor cell lines. Compound $\mathbf{2}$ is a demethylidene analog of $\mathbf{1}$ and also a constitutional isomer of YM-216391. Compound 2 and YM-216391 differ only in the position of the thiazole ring inside the penta-azole structure of the macrocycle. ${ }^{13}$ The open ring precursors 9a-e are generally inactive; only $\mathbf{9 c}$ is moderately active against two tumor cell lines at $\mu \mathrm{M}$ concentrations. The azole analogs ${ }^{14}$ of $\mathbf{1}$ recently obtained by our group, which do not contain the central thiazole, were also inactive. These results demonstrate the importance of the thiazole for the activity of these macrocyclic compounds.

Thiopeptide $\mathbf{1}$ and the most active analogs $\mathbf{2}$ and $\mathbf{3 c}$ were then selected for further biological evaluation.

Effects of 1, 2 and 3c on cell cycle progression of HT-29, A-549 and MDA-MB-231 cells

Thiopeptide $\mathbf{1}$ is closely related in structure to potent telomerase inhibitors such as telomestatin. Telomerase generates telomere repeats, specialized structures located at the end of eukaryotic chromosomes. Telomeres are important for maintenance of genomic stability and integrity during cell proliferation. Thiopeptide $\mathbf{1}$ and their analogs $\mathbf{2}$ and $\mathbf{3 c}$ were tested for effects on cell cycle progression in HT-29, A-549 and MDA-MB-231 tumor cells. The cells were treated with each compound (see Material and Methods), and then analyzed by flow cytometry to determine if the cell cycle had been arrested at a specific phase. A control set of untreated cells was also used. 
Compared to the control cells (Figure 2, panels 1a-c), the cells treated with 1 (Figure 2, panels $2 \mathrm{a}-\mathrm{c}$ ) and with compound $\mathbf{2}$ (Figure 2, panels $3 \mathrm{a}-\mathrm{c}$ ) had higher population stopped at the G2 phase, except A-549 cells treated with compound 2 that showed enlarged arrest in $\mathrm{S}$ phase. Nervertheless, cells treated with compound $\mathbf{3 c}$ showed a very pronounced arrest in S phase in all cell lines (Figure 2, panels 4a-c). Hence, these compounds alter cell cycle progression.

Figure 2 Cell cycle progression in cancer cell lines treated with either 1, 2 or $3 \mathrm{c}$
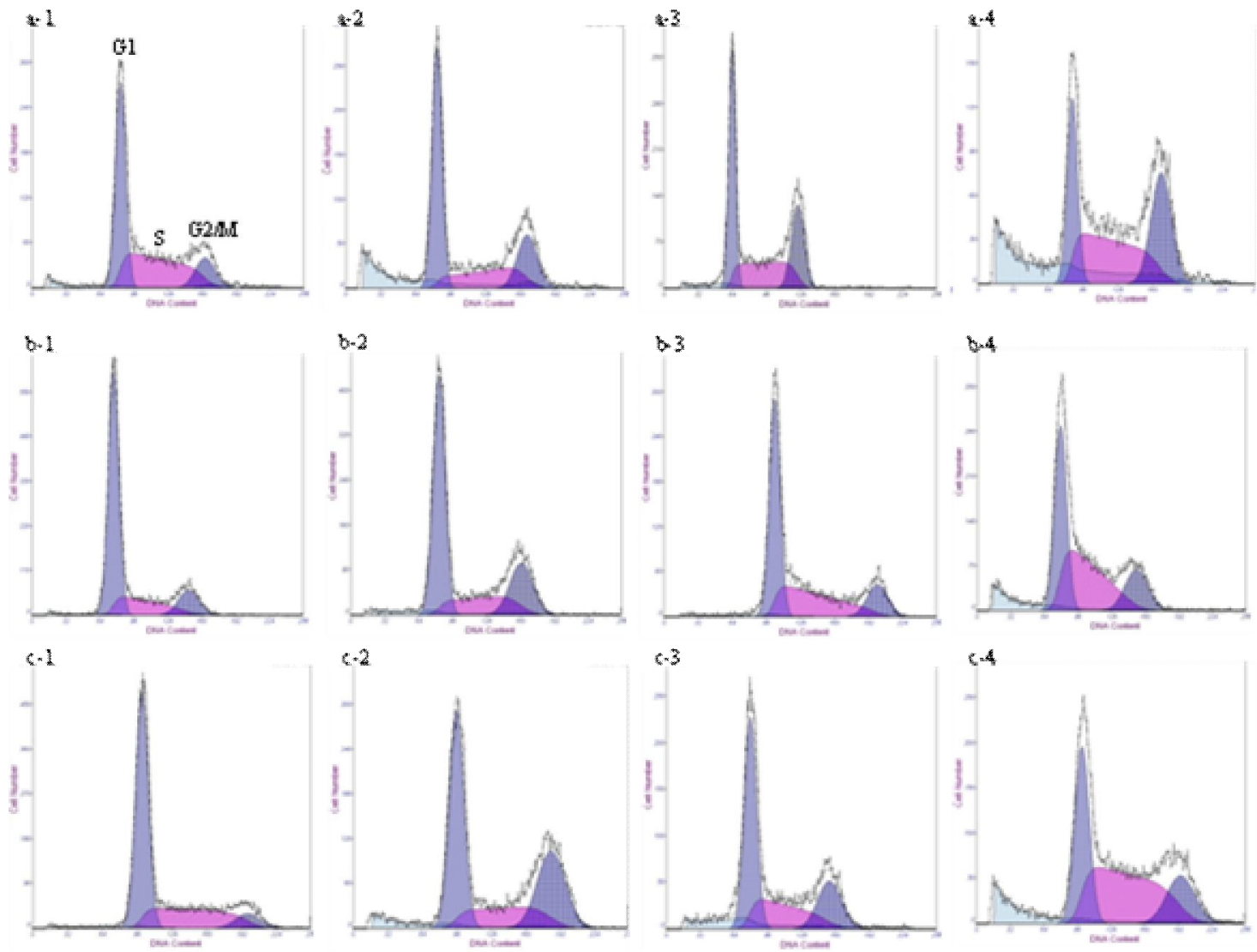

\begin{tabular}{|c|c|c|c|c|c|c|c|c|c|c|c|c|}
\hline \multirow{2}{*}{$\begin{array}{l}\text { Phase of } \\
\text { Cell Cycle }\end{array}$} & \multicolumn{4}{|c|}{ HT-29 } & \multicolumn{4}{|c|}{ A-549 } & \multicolumn{4}{|c|}{ MDA-MB-231 } \\
\hline & a-1 & $a-2$ & $a-3$ & $a-4$ & b-1 & b-2 & b-3 & $\overline{b-4}$ & c-1 & $c-2$ & $c-3$ & $\overline{c-4}$ \\
\hline G1 (\%) & 45.5 & 51.3 & 39.7 & 27.2 & 66.3 & 55.5 & 50.4 & 40.0 & 60.9 & 46.4 & 50.3 & 33.6 \\
\hline $\mathrm{G} 2 / \mathrm{M}(\%)$ & 12.9 & 22.4 & 27.2 & 31.4 & 13.0 & 22.8 & 14.2 & 16.7 & 7.5 & 31.3 & 21.8 & 17.3 \\
\hline
\end{tabular}




\footnotetext{
\begin{tabular}{l|llllllllllll} 
S (\%) & 41.4 & 26.2 & 33.0 & 41.2 & 20.6 & 21.6 & 35.3 & 43.1 & 31.5 & 22.2 & 27.8 & 49.0
\end{tabular}

a-1: HT-29 asynchronous colon cell line; a-2: HT-29 with thiopeptide 1; a-3: HT-29 with compound 2; a-4: HT-29 with compound 3c; b-1: A-549 asynchronous lung cell line; b-2: A-549 with thiopeptide 1; b-3: A549 with compound 2; b-4: A-549 with compound 3c; c-1: MDA-MB-231 asynchronous breast cell line; c2: MDA-MB-231 with thiopeptide 1; c-3: MDA-MB-231 with compound 2; c-4: MDA-MB-231 with compound 3c.
}

Induction of apoptosis by either thiopeptide 1, 2 or 3c in HT-29, A-549 and MDA-MB-

\section{1 cell lines}

Many anticancer drugs induce cell cycle arrest and apoptosis. Apoptotic cells undergo characteristic morphological changes. Among these, the cell surface often bends and breaks up into membrane-enclosed fragments called apoptotic bodies. This process depends on a cascade of proteolytic enzymes called caspases. ${ }^{15}$ They exist in most of the cells as inactive precursors (zymogens) that, once activated, kill cells.

To analyze whether 1, 2 and 3c induce apoptosis, HT-29, A-549, MDA-MB-231 cell lines were incubated with each compound and then qualitatively measured for apoptosis (see Experimental Section). The analysis consisted of detecting active caspases (caspase3/7) using a colorimetric test (CaspaTag In situ Caspase Detection Kits, CHEMICON).

All cell lines showed a high level of apoptotic cell death after treatment with either $\mathbf{1}$ (Figure 3, panels 2a-c), compound 2 (Figure 3, panels 3a-c) and compound 3c (Figure 3, panels $4 \mathrm{a}-\mathrm{c})$. A negative control of the assay was performed by analyzing untreated cells under the same experimental conditions (Figure 3, panels 1a-c). 
Figure 3 Analysis of apoptotic cell death in cancer cells treated with either thiopeptide 1,2 or $3 \mathrm{c}$

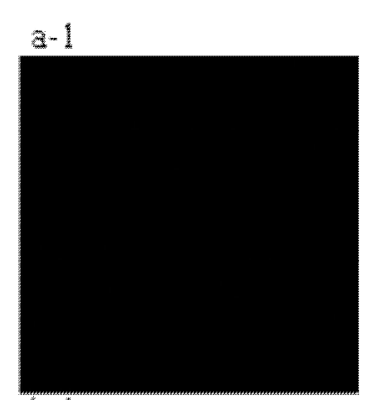

$b-1$

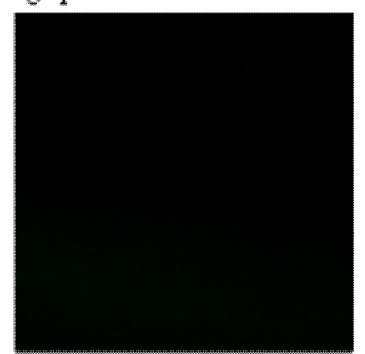

$\mathrm{C}-1$

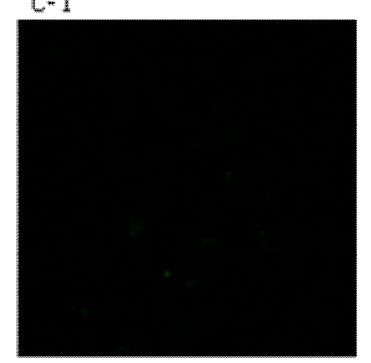

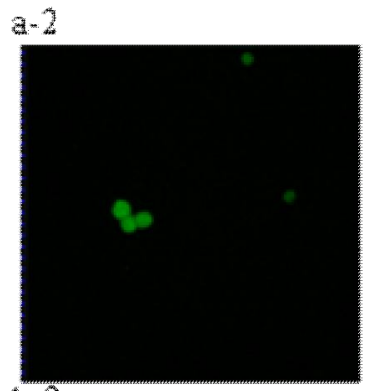

$b-2$
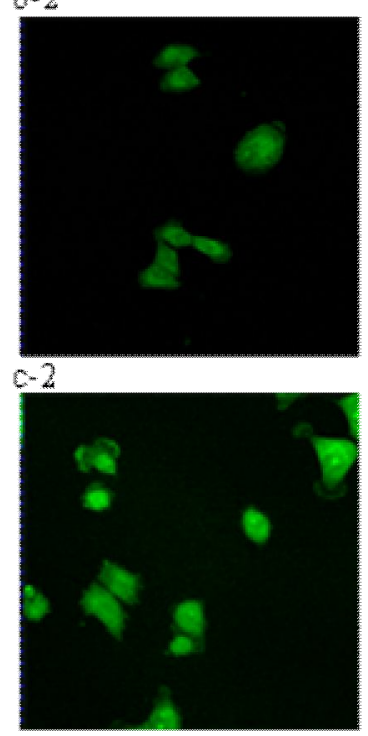

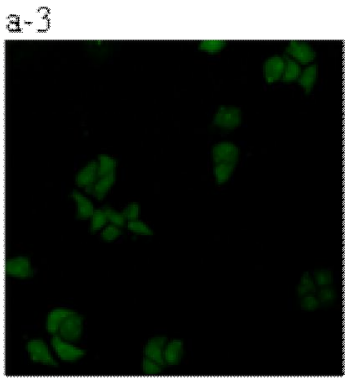

b-3

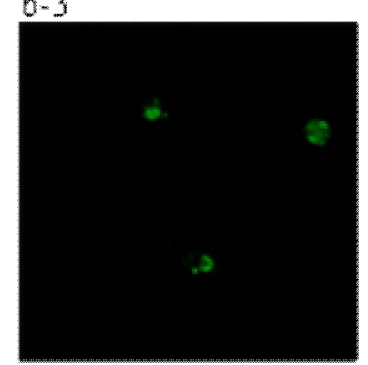

c. 3

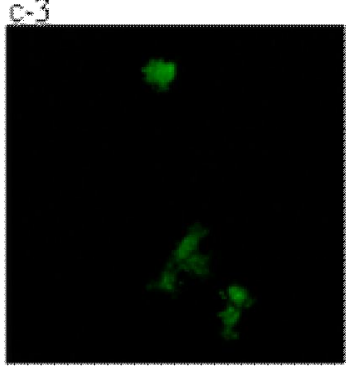

a-4

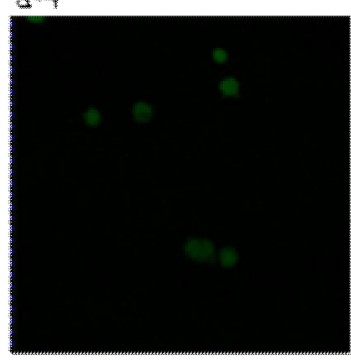

b4

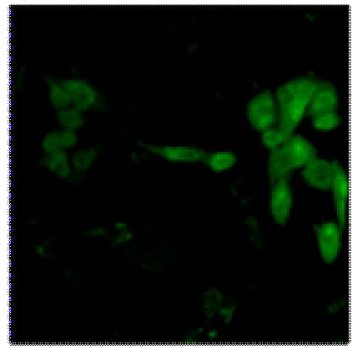

$c-4$

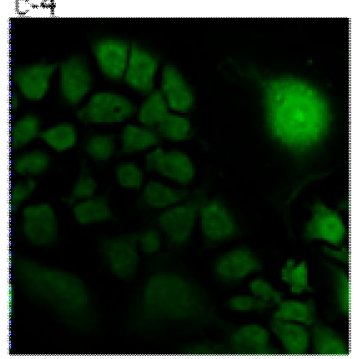

a-1: HT-29 colon cell line negative control; a-2: HT-29 with compound thiopeptide 1; a3: HT-29 with compound 2; a-4: HT-29 with compound 3c; b-1: A-549 lung cell line negative control; b-2: A-549 with compound thiopeptide 1; b-3: A-549 with compound 2; b-4: A-549 with compound 3c; c-1: MDA-MB-231 breast cell line negative control; c-2: MDA-MB-231 with compound thiopeptide 1; c-3: MDA-MB-231 with compound 2; c-4: MDA-MB-231 with compound 3c.

\section{CONCLUSION}

Several analogs of thiopeptide $\mathbf{1}$ were synthesized using slight variations of a methodology previously described for the preparation of the parent compound. Conditions that allow isolation of the hydroxymethyl derivative have been established, 
thus enabling preparation of several analogs by acylation. Methyl substituents were introduced onto the penta-azole system by employing different starting materials, whereas the exocyclic double bond was modified in the last synthetic step.

Thiopeptide 1, and analogs $\mathbf{2}$ and $\mathbf{3 c}$ were shown to inhibit cell cycle progression in cancer cell lines. As previously mentioned, $\mathbf{1}$ is closely related in structure to YM$216391^{9}$ and the potent telomerase inhibitor telomestatin. ${ }^{5}$

Telomerase activity is important during telomere replication in chromosomes, thus telomerase inhibition will cause replication faults and DNA damage effect, which would in turn affect cell cycle progression. We observed that $\mathbf{1}$ and compound $\mathbf{2}$ caused cells to accumulate mainly in G2 phase, which could activate the G2-checkpoint activation. In contrast, $\mathbf{3 c}$, by though less active than $\mathbf{1}$, provoked major $\mathrm{S}$ phase arrest in all cell lines, indicating that it has potent biological activity related to DNA replication. Moreover, the effects observed consecutively to the treatment of cells with $\mathbf{3 c}$ resemble those expected for a telomerase inhibitor.

Perturbation of the cell cycle induces activation of apoptosis and leads to cell cycle arrest. Different cancer cell lines treated with either $\mathbf{1}, \mathbf{2}$ and $\mathbf{3 c}$ specifically underwent apoptosis, thereby indicating that these compounds do not act by some general toxicity mechanism. These compounds inhibit cell division and activate programmed cell death by apoptosis.

The resemblance among $\mathbf{1}$, its analogs $\mathbf{2}, \mathbf{3 c}$ and known telomerase inhibitors, together with the fact that the majority of human tumors seem to depend on telomerase reactivation to prevent critical telomere loss, are testament to the potential of exploring these compounds as anticancer therapies. 


\section{EXPERIMENTAL SECTION}

General data see the supporting information.

Compounds $4 \mathbf{a}, 5 \mathbf{a}, \mathbf{6}, 7 \mathbf{a}, 8 \mathbf{a}$ and $9 \mathbf{a}$ were synthesized as previously reported. ${ }^{8}$

\section{Macrocyclization-Elimination reaction for preparation of 1a-c}

A solution of $9(1.0 \mathrm{mmol})$ in $98 \% \mathrm{HCO}_{2} \mathrm{H}(28 \mathrm{~mL})$ was stirred under reflux for $1 \mathrm{~h}$. The reaction mixture was cooled, poured into a solution of $\mathrm{NaHCO}_{3}$, and then extracted with $\mathrm{CH}_{2} \mathrm{Cl}_{2}$. The organic layer was dried, and then concentrated in vacuo to give the ketoand $O$-deprotected product as a yellow oil. A solution of this oil in $\mathrm{EtOH}(70 \mathrm{~mL})$ was stirred at $85{ }^{\circ} \mathrm{C}$ for $48 \mathrm{~h}$. Concentration in vacuo gave a brown residue, which was purified on the Isco Flash system with a RediSep silica gel disposable flash column. Elution with $\mathrm{CH}_{2} \mathrm{Cl}_{2}-\mathrm{MeOH}(9: 1)$ gave the $O$-deprotected product as a yellow oil. This product was dissolved in dry $\mathrm{CH}_{2} \mathrm{Cl}_{2}(20 \mathrm{~mL})$, and the solution was cooled to $0{ }^{\circ} \mathrm{C}$. TEA $(2.48 \mathrm{mmol})$ and $\mathrm{MsCl}(1.24 \mathrm{mmol})$ were then added dropwise. The resulting solution was stirred for $5 \mathrm{~h}$ at $0{ }^{\circ} \mathrm{C}$, washed with $\mathrm{NH}_{4} \mathrm{Cl}$ and water, dried, and concentrated.

Peptide-heterocycle (1a) The final product was purified by preparative HPLC using $\mathrm{H}_{2} \mathrm{O}$ $(0.045 \%$ TFA) and $\mathrm{MeCN}(0.036 \%$ TFA) as eluents (gradient: $40 \%$ to $80 \%$ in $25 \mathrm{~min}$; flow rate: $3 \mathrm{~mL} / \mathrm{min})$ to afford $\mathbf{1 a}(65.4 \mathrm{mg}, 10 \%)$ as a yellow solid. m.p. $\left(\mathrm{CHCl}_{3}\right) 165$ $167{ }^{\circ} \mathrm{C} .[\alpha]_{\mathrm{D}}+16.8$ (c 0.25, DMF). ${ }^{1} \mathrm{H}$ NMR (DMF, $\left.400 \mathrm{MHz}\right) \delta$ 0.81-1.07 (m, 12H); $1.22-1.32(\mathrm{~m}, 1 \mathrm{H}) ; 1.52-1.69(\mathrm{~m}, 1 \mathrm{H}) ; 1.92-2.02(\mathrm{~m}, 1 \mathrm{H}) ; 2.04-2.15(\mathrm{~m}, 1 \mathrm{H}) ; 2.77(\mathrm{~s}$, $3 \mathrm{H}) ; 4.42(\mathrm{dd}, J=6.8$ and $9.6 \mathrm{~Hz}, 1 \mathrm{H}) ; 4.79-4.82(\mathrm{~m}, 1 \mathrm{H}) ; 5.69(\mathrm{~s}, 1 \mathrm{H}) ; 6.19(\mathrm{~s}, 1 \mathrm{H})$; 7.50-7.61 (m, 3H); 8.50-8.53 (m, 2H); 8.59 (s, 1H); 8.64 (bs, 1H); 8.91 (bs, 1H); 9.16 (s, 1H); 9.19 (s, 1H); 10.22 (bs, 1H). ${ }^{13} \mathrm{C}$ NMR (DMF, $\left.100 \mathrm{MHz}\right) \delta 11.4$ (q); 11.7 (q); 13.6 (q); 18.7 (q); $19.3(\mathrm{q}) ; 26.7$ (t); 31.8 (d); 39.7 (d); $55.6(\mathrm{~d}) ; 60.6(\mathrm{~d}) ; 104.5$ (t); 121.3 (d); 
127.0 (s); 127.9 (2d); 128.0 (s); 128.2 (s); 128.6 (2d); 129.3 (s); 130.2 (d); 130.7 (s); 136.0 (s); 138.1 (s); 139.5 (d); 140.4 (d); 143.0 (s); 151.5 (s); 153.6 (s); 155.5 (s); 155.8 (s); 156.5 (s); 157.5 (s); 157.9 (s); 171.0 (s); 172.2 (s). MS (MALDI-TOF) m/z 761 (M + $\mathrm{K}, 100), 745(\mathrm{M}+\mathrm{Na}, 85) . \mathrm{HRMS} \mathrm{m} / \mathrm{z}$ calcd. for $\mathrm{C}_{36} \mathrm{H}_{38} \mathrm{~N}_{9} \mathrm{O}_{7} \mathrm{~S}\left(\mathrm{M}+\mathrm{NH}_{4}\right) 740.2609$ found 740.2602 .

Peptide-heterocycle (1b) The final product was purified by preparative HPLC using $\mathrm{H}_{2} \mathrm{O}$ $(0.045 \%$ TFA) and MeCN $(0.036 \%$ TFA) as eluents (gradient: 40 to 80 in 25 min; flow $3 \mathrm{~mL} / \mathrm{min})$ to afford $\mathbf{1 b}(51.1 \mathrm{mg}, 7 \%)$ as a yellow solid m.p. $\left(\mathrm{CHCl}_{3}\right) 160-162{ }^{\circ} \mathrm{C} .[\alpha]_{\mathrm{D}}$ +18.4 (c 0.19, DMF). ${ }^{1} \mathrm{H}$ NMR (DMF, $\left.400 \mathrm{MHz}\right) \delta$ 0.81-1.01 (m, 12H); 1.21-1.33 (m, $1 \mathrm{H}) ; 1.48-1.61(\mathrm{~m}, 1 \mathrm{H}) ; 1.95-2.03(\mathrm{~m}, 1 \mathrm{H}) ; 2.06-2.16(\mathrm{~m}, 1 \mathrm{H}) ; 2.94(\mathrm{~s}, 3 \mathrm{H}) ; 4.41(\mathrm{dd}, J=$ 6.4 and $9.4 \mathrm{~Hz}, 1 \mathrm{H}) ; 4.81-4.84(\mathrm{~m}, 1 \mathrm{H}) ; 5.77(\mathrm{~s}, 1 \mathrm{H}) ; 6.22(\mathrm{~s}, 1 \mathrm{H}) ; 7.49-7.62(\mathrm{~m}, 3 \mathrm{H})$; $8.51(\mathrm{~s}, 1 \mathrm{H}) ; 8.54-8.56(\mathrm{~m}, 2 \mathrm{H}) ; 8.64$ (bs, 1H); 8.90 (bs, 1H); 9.0 (s, 1H); $9.14(\mathrm{~s}, 1 \mathrm{H})$; 10.30 (bs, 1H). ${ }^{13} \mathrm{C}$ NMR (DMF, $\left.100 \mathrm{MHz}\right) \delta 11.2$ (q); 11.7 (q); 13.6 (q); 18.7 (q); 19.3 (q); 26.7 (t); 31.7 (d); 39.8 (d); 55.6 (d); 60.7 (d); $105.4(\mathrm{t}) ; 125.6(\mathrm{~d}) ; 127.2$ (s); 127.8 (2d); 128.1 (s); 128.5 (s); 128.7 (2d); 129.3 (s); 130.1 (d); 132.4 (s); 135.4 (s); 136.5 (s); 139.5 (d); 140.7 (d); 143.6 (s); 151.4 (s); 153.3 (s); 156.2 (s); 158.4 (s); 159.0 (s); 159.6 (s); 160.3 (s); 171.1 (s); 172.3 (s). MS (MALDI-TOF) m/z 761 (M + K, 100), 745 (M + $\mathrm{Na}, 85)$, HRMS m/z calcd. for $\mathrm{C}_{36} \mathrm{H}_{38} \mathrm{~N}_{9} \mathrm{O}_{7} \mathrm{~S}\left(\mathrm{M}+\mathrm{NH}_{4}\right) 740.2609$ found 740.2585 .

Peptide-heterocycle (1c) The final product was purified by preparative $\mathrm{HPLC}$ using $\mathrm{H}_{2} \mathrm{O}$ $(0.045 \% \mathrm{TFA})$ and $\mathrm{MeCN}(0.036 \% \mathrm{TFA})$ as eluents (gradient: $50 \%$ to $90 \%$ in $25 \mathrm{~min}$; flow rate: $3 \mathrm{~mL} / \mathrm{min})$ to afford $\mathbf{1 c}(75 \mathrm{mg}, 8 \%)$ as a yellow solid m.p. $\left(\mathrm{CHCl}_{3}\right)$ 155-157 ${ }^{\circ} \mathrm{C} .[\alpha]_{\mathrm{D}}+18.6$ (c 0.16, DMF). ${ }^{1} \mathrm{H}$ NMR (DMF, $\left.500 \mathrm{MHz}\right) \delta 0.81-1.08$ (m, 12H); 1.20$1.33(\mathrm{~m}, 1 \mathrm{H}) ; 1.47-1.59(\mathrm{~m}, 1 \mathrm{H}) ; 1.95-2.02(\mathrm{~m}, 1 \mathrm{H}) ; 2.08-2.16(\mathrm{~m}, 1 \mathrm{H}) ; 2.79(\mathrm{~s}, 3 \mathrm{H})$ 
$2.95(\mathrm{~s}, 3 \mathrm{H}) ; 4.42(\mathrm{dd}, J=5.6$ and $11.4 \mathrm{~Hz}, 1 \mathrm{H}) ; 4.82(\mathrm{~m}, 1 \mathrm{H}) ; 5.70(\mathrm{~s}, 1 \mathrm{H}) ; 6.19(\mathrm{~s}, 1 \mathrm{H})$; 7.53-7.61 (m, 3H); $8.51(\mathrm{~s}, 1 \mathrm{H}) ; 8.56-8.57$ (m, 2H); 8.63 (bs, 1H); 8.93 (bs, 1H); 9.16 (s, 1H); 10.26 (bs, 1H). ${ }^{13} \mathrm{C}$ NMR (DMF, $\left.125 \mathrm{MHz}\right) \delta 11.6$ (q); 11.9 (q); 12.1 (q); 14.3 (q); 14.5 (q); 19.8 (q); 28.9 (t); 31.3 (d); 38.6 (d); 58.0 (d); 61.0 (d); 103.3 (t); 124.9 (d); 128.7 (2d); 129.6 (2d); 130.8 (d); 138.6 (d). MS (MALDI-TOF) m/z 775 (M + K, 100), $759(\mathrm{M}+\mathrm{Na}, 85) . \mathrm{HRMS} \mathrm{m} / \mathrm{z}$ calcd. for $\mathrm{C}_{37} \mathrm{H}_{40} \mathrm{~N}_{9} \mathrm{O}_{7} \mathrm{~S}\left(\mathrm{M}+\mathrm{NH}_{4}\right) 754.2765$ found 754.2764 .

Peptide-heterocycle (2) A solution of $9 \mathrm{e}(0.85 \mathrm{~g}, 1.01 \mathrm{mmol})$ in $98 \% \mathrm{HCO}_{2} \mathrm{H}(25 \mathrm{~mL})$ was refluxed for $1 \mathrm{~h}$. The cool reaction mixture was poured into a solution of $\mathrm{NaHCO}_{3}$ and extracted with $\mathrm{CH}_{2} \mathrm{Cl}_{2}$. The organic layer was dried, and concentrated in vacuo to give the keto-deprotected product as a yellow oil. A solution of the oil in ethanol $(80 \mathrm{~mL})$ was stirred at $85^{\circ} \mathrm{C}$ for $48 \mathrm{~h}$. Concentration in vacuo gave a brown residue, which was purified by chromatography on silica gel. Elution with $\mathrm{CH}_{2} \mathrm{Cl}_{2}-\mathrm{MeOH}$ (100 to 95:5) and final purification was achieved by Isco Flash (4.3 gram Reverse Phase C18 RediSep column); $\mathrm{H}_{2} \mathrm{O}(0.04 \%$ TFA) and $\mathrm{MeCN}(0.04 \%$ TFA) as eluents (gradient: $5 \%$ to $20 \%$ in $40 \mathrm{~min}$; flow rate: $13 \mathrm{~mL} / \mathrm{min})$ to afford $2(73 \mathrm{mg}, 11 \%)$ as a yellow solid. m.p. $\left(\mathrm{CHCl}_{3}\right)$ 185-187 ${ }^{\circ} \mathrm{C} .[\alpha]_{\mathrm{D}}+40.1$ (c 3.13, DMSO). ${ }^{1} \mathrm{H}$ NMR (DMSO, $\left.400 \mathrm{MHz}\right) \delta$ 0.85-0.92 (m, $9 \mathrm{H}) ; 0.98(\mathrm{~d}, J=6.8 \mathrm{~Hz}, 3 \mathrm{H}) ; 1.03-1.10(\mathrm{~m}, 2 \mathrm{H}) ; 1.58-1.64(\mathrm{~m}, 1 \mathrm{H}) ; 2.02-2.15(\mathrm{~m}, 1 \mathrm{H})$; 4.19-4.24 (m, 1H); 4.44-4.50 (m, 1H); 4.69-4.74 (m, 1H); $4.98(\mathrm{dd}, J=9.2$ and $16.8 \mathrm{~Hz}$, $1 \mathrm{H}) ; 7.51-7.58(\mathrm{~m}, 4 \mathrm{H}) ; 8.33(\mathrm{~d}, J=7.2 \mathrm{~Hz}, 2 \mathrm{H}) ; 8.40(\mathrm{~d}, J=7.2 \mathrm{~Hz}, 1 \mathrm{H}) ; 8.52(\mathrm{~s}, 1 \mathrm{H})$; $8.67(\mathrm{~d}, J=8.8 \mathrm{~Hz}, 1 \mathrm{H}) ; 8.8(\mathrm{~s}, 1 \mathrm{H}) ; 9.05(\mathrm{~s}, 1 \mathrm{H}) ; 9.12(\mathrm{~s}, 1 \mathrm{H}) .{ }^{13} \mathrm{C}$ NMR (DMSO, 100 MHz) $\delta 11.8(\mathrm{q}) ; 14.5(\mathrm{q}) ; 17.5(\mathrm{q}) ; 19.6(\mathrm{q}) ; 25.4(\mathrm{t}) ; 31.1(\mathrm{~d}) ; 55.2(\mathrm{~d}) ; 57.0(\mathrm{~d}) ; 57.5$ (d); 69.5 (t); 121.2 (d); 126.4 (s); 127.2 (d); 127.5 (s); 128.4 (2d); 129.1 (s); 129.4 (s); 
129.9 (2d); 135.4 (s); 139.0 (d); 139.5 (d); 140.1 (s); 141.2 (d); 150.5 (s); 152.0 (s); 154.9 (s); 157.3 (s); 159.8 (s); 162.6 (s); 170.0 (s); 170.2 (s); 170.6 (s). MS (ES) m/z 714 (M + $\left.\mathrm{NH}_{4}, 100\right), 316$ (5), 288 (18). HRMS m/z calcd. for $\mathrm{C}_{34} \mathrm{H}_{33} \mathrm{~N}_{8} \mathrm{O}_{7} \mathrm{~S} 697.2187(\mathrm{M}+\mathrm{H})$ found 697.2187

\section{Macrocyclization-Acylation for preparation of 3a-d}

A solution of $9(0.72 \mathrm{mmol})$ in $98 \% \mathrm{HCO}_{2} \mathrm{H}(20 \mathrm{~mL})$ was stirred under reflux $1 \mathrm{~h}$. The reaction mixture was cooled, poured into a solution of $\mathrm{NaHCO}_{3}$, and then extracted with $\mathrm{CH}_{2} \mathrm{Cl}_{2}$. The organic layer was dried, and concentrated to give the keto- and $O$ deprotected product as a yellow oil. A solution of the oil in EtOH $(40 \mathrm{~mL})$ was stirred at $85^{\circ} \mathrm{C}$ for $48 \mathrm{~h}$. Concentration in vacuo gave a brown residue, which, upon elution with $\mathrm{CH}_{2} \mathrm{Cl}_{2}-\mathrm{MeOH}(9: 1)$, gave the alcohol 3 as a yellow oil.

Peptide-heterocycle (3a) The alcohol 3 (105 mg, $0.14 \mathrm{mmol})$ was dissolved in dry THF $(20 \mathrm{~mL}) . \mathrm{Ac}_{2} \mathrm{O}(0.45 \mathrm{~mL}, 4.82 \mathrm{mmol})$ was then added dropwise. The resulting solution was stirred for $8 \mathrm{~h}$ at room temperature, washed with $\mathrm{NaHCO}_{3}$, dried, and concentrated. The final product was purified by preparative HPLC using $\mathrm{H}_{2} \mathrm{O}(0.04 \%$ TFA) and MeCN (0.04\% TFA) as eluents (gradient: $20 \%$ to $40 \%$ in $50 \mathrm{~min}$; flow rate: $15 \mathrm{~mL} / \mathrm{min}$ ) to afford 3a $(15 \mathrm{mg}, 13 \%)$ as a yellow solid m.p. $\left(\mathrm{CHCl}_{3}\right) 171-173{ }^{\circ} \mathrm{C} .[\alpha]_{\mathrm{D}}+71.8(c 0.47$, $\left.\mathrm{CHCl}_{3}\right) .{ }^{1} \mathrm{H} \mathrm{NMR}\left(\mathrm{CDCl}_{3}, 400 \mathrm{MHz}\right) \delta$ 0.93-1.01 (m, 12H); 1.28-1.35 (m, 2H); 1.63-1.75 $(\mathrm{m}, 1 \mathrm{H}) ; 1.85-1.95(\mathrm{~m}, 1 \mathrm{H}) ; 2.04(\mathrm{~s}, 3 \mathrm{H}) ; 3.59-3.68(\mathrm{~m}, 1 \mathrm{H}) ; 4.32-4.49(\mathrm{~m}, 1 \mathrm{H}) ; 4.65-$ $4.75(\mathrm{~m}, 2 \mathrm{H}) ; 5.75-5.84(\mathrm{~m}, 1 \mathrm{H}) ; 6.15-6.24(\mathrm{bs}, 1 \mathrm{H}) ; 7.42-7.53(\mathrm{~m}, 4 \mathrm{H}) ; 7.95(\mathrm{~s}, 1 \mathrm{H})$; $8.19(\mathrm{~s}, 1 \mathrm{H}) ; 8.26(\mathrm{~s}, 2 \mathrm{H}) ; 8.36(\mathrm{~d}, J=7.2 \mathrm{~Hz}, 2 \mathrm{H}) ; 8.55(\mathrm{bs}, 1 \mathrm{H}) .{ }^{13} \mathrm{C} \mathrm{NMR}\left(\mathrm{CDCl}_{3}, 100\right.$ MHz) $\delta 11.8$ (q); 14.5 (q); 18.8 (q); 18.9 (q); 20.4 (q); 25.7 (d); 29.6 (t); 30.1 (d); 39.7 (d); 47.0 (d); 56.5 (d); $63.6(\mathrm{t}) ; 119.6$ (d); 126.5 (s); 127.2 (s); 128.0 (d); 128.5 (2d); 
129.4 (s); 130.0 (s); 130.2 (s); 130.3 (2d); 135.7 (d); 137.4 (s); 137.7 (d); 139.8 (d); 141.8 (s); 151.4 (s); 153.0 (s); 156.0 (s); 158.2 (s); 160.4 (s); 162.4 (s); 170.8 (s); 171.7 (s); 172.0 (s). MS (ES) m/z $786\left(\mathrm{M}+\mathrm{NH}_{4}, 100\right), 744$ (12), 316 (12), 288 (38), 241 (12). HRMS m/z calcd. for $\mathrm{C}_{37} \mathrm{H}_{37} \mathrm{~N}_{8} \mathrm{O}_{9} \mathrm{~S} 769.2399(\mathrm{M}+\mathrm{H})$ found 769.2409.

Peptide-heterocycle (3b) The alcohol $3(87 \mathrm{mg}, 0.12 \mathrm{mmol})$ was dissolved in dry $\mathrm{CH}_{2} \mathrm{Cl}_{2}(10 \mathrm{~mL})$. 2-(2-methoxyethoxy) acetic acid (0.156 mL, $\left.1.37 \mathrm{mmol}\right)$, EDC.HCl (263 mg, $1.37 \mathrm{mmol})$ and DMAP (25 $\mathrm{mg}, 0.21 \mathrm{mmol})$ were then added. The resulting solution was stirred for $8 \mathrm{~h}$ at room temperature, washed with $\mathrm{NaHCO}_{3}$, dried and concentrated. The final product was purified by preparative HPLC using $\mathrm{H}_{2} \mathrm{O}(0.04 \%$ TFA) and $\mathrm{MeCN}(0.04 \%$ TFA) as eluents (gradient: $20 \%$ to $38 \%$ in $70 \mathrm{~min}$; flow rate: 15 $\mathrm{mL} / \mathrm{min})$ to afford $\mathbf{3 b}(13 \mathrm{mg}, 13 \%)$ as a yellow solid m.p. $\left(\mathrm{CHCl}_{3}\right) 145-147{ }^{\circ} \mathrm{C} .[\alpha]_{\mathrm{D}}-$ $30.2\left(c\right.$ 0.61, $\left.\mathrm{CHCl}_{3}\right) .{ }^{1} \mathrm{H} \mathrm{NMR}\left(\mathrm{CDCl}_{3}, 400 \mathrm{MHz}\right) \delta$ 0.84-1.07 (m, 12H); 1.26-1.35 (m, $2 \mathrm{H}) ; 1.52-1.75(\mathrm{~m}, 1 \mathrm{H}) ; 1.81-1.96(\mathrm{~m}, 1 \mathrm{H}) ; 3.34(\mathrm{~s}, 3 \mathrm{H}) ; 3.53-3.71(\mathrm{~m}, 6 \mathrm{H}) ; 4.09-4.22$ $(\mathrm{m}, 2 \mathrm{H}) ; 4.46-4.56(\mathrm{~m}, 1 \mathrm{H}) ; 4.59-4.81(\mathrm{~m}, 1 \mathrm{H}) ; 5.55(\mathrm{bs}, 1 \mathrm{H}) ; 5.73-5.80(\mathrm{~m}, 1 \mathrm{H}) ; 7.41-$ $7.51(\mathrm{~m}, 4 \mathrm{H}) ; 7.94(\mathrm{~s}, 1 \mathrm{H}) ; 8.20(\mathrm{~s}, 1 \mathrm{H}) ; 8.24(\mathrm{~s}, 1 \mathrm{H}) ; 8.27(\mathrm{~s}, 1 \mathrm{H}) ; 8.34(\mathrm{~d}, J=8.0 \mathrm{~Hz}$, 2H); 8.57 (bs, 1H). ${ }^{13} \mathrm{C} \mathrm{NMR}\left(\mathrm{CDCl}_{3}, 100 \mathrm{MHz}\right) \delta 11.8$ (q); 14.2 (q); 18.7 (q); 18.8 (q); $25.8(\mathrm{~d}) ; 29.6(\mathrm{t}) ; 39.6(\mathrm{~d}) ; 46.7(\mathrm{~d}) ; 56.3(\mathrm{~d}) ; 58.8(\mathrm{q}) ; 59.7(\mathrm{~d}) ; 67.9(\mathrm{t}) ; 69.9(\mathrm{t}) ; 70.5(\mathrm{t}) ;$ $71.6(\mathrm{t}) ; 119.6$ (d); 126.5 (s); 127.9 (s); 128.4 (d); 128.5 (2d); 129.9 (s); 130.3 (s); 130.3 (s); 130.4 (2d); 135.7 (s); 137.5 (d); 137.7 (d); 139.7 (d); 139.9 (s); 141.8 (s); 151.3 (s); 152.9 (s); 158.0 (s); 158.3 (s); 160.4 (s); 170.3 (s); 171.8 (s); 172.0 (s). MS (ES) m/z 860 $\left(\mathrm{M}+\mathrm{NH}_{4}, 100\right), 744$ (55), 726 (45), 316 (45), 288 (98), 242 (22). HRMS m/z calcd. for $\mathrm{C}_{40} \mathrm{H}_{43} \mathrm{~N}_{8} \mathrm{O}_{11} \mathrm{~S} 843.2750(\mathrm{M}+\mathrm{H})$ found 843.6727. 
Peptide-heterocycle (3c) The alcohol $3(111 \mathrm{mg}, 0.15 \mathrm{mmol})$ was dissolved in dry $\mathrm{CH}_{2} \mathrm{Cl}_{2}(10 \mathrm{~mL}) .2$-[2-(2-methoxyethoxy)ethoxy]acetic acid $(0.25 \mathrm{~mL}, 1.65 \mathrm{mmol})$, EDC.HCl (316 mg, $1.65 \mathrm{mmol})$ and DMAP (30 mg, $0.25 \mathrm{mmol})$ were then added dropwise. The resulting solution was stirred for $8 \mathrm{~h}$ at room temperature, washed with $\mathrm{NaHCO}_{3}$, dried and concentrated. The final product was purified by preparative HPLC using $\mathrm{H}_{2} \mathrm{O}(0.04 \%$ TFA) and $\mathrm{MeCN}(0.04 \%$ TFA) as eluents (gradient: $20 \%$ to $38 \%$ in 70 min; flow rate: $15 \mathrm{~mL} / \mathrm{min})$ to afford $3 \mathrm{c}(16 \mathrm{mg}, 12 \%)$ as a yellow solid m.p. $\left(\mathrm{CHCl}_{3}\right)$ $139-141{ }^{\circ} \mathrm{C} .[\alpha]_{\mathrm{D}}-63.4\left(c 0.56, \mathrm{CHCl}_{3}\right) . \delta{ }^{1} \mathrm{H} \mathrm{NMR}(\mathrm{DMF}, 400 \mathrm{MHz}) \delta 0.93-0.98(\mathrm{~m}$, $6 \mathrm{H}) ; 1.01(\mathrm{~d}, J=6.8 \mathrm{~Hz}, 3 \mathrm{H}) ; 1.07(\mathrm{~d}, J=6.8 \mathrm{~Hz}, 3 \mathrm{H}) ; 1.24-1.30(\mathrm{~m}, 2 \mathrm{H}) ; 1.38(\mathrm{~d}, J=$ $6.4 \mathrm{~Hz}, 1 \mathrm{H}) ; 1.54-1.74(\mathrm{~m}, 1 \mathrm{H}) ; 2.11-2.28(\mathrm{~m}, 1 \mathrm{H}) ; 3.28(\mathrm{~s}, 3 \mathrm{H}) ; 3.55-3.70(\mathrm{~m}, 10 \mathrm{H})$; 4.08-4.20 (m, 2H); 4.70-4.79 (m, 2H); $5.82(\mathrm{~s}, 1 \mathrm{H}) ; 6.17(\mathrm{~s}, 1 \mathrm{H}) ; 7.49-7.61(\mathrm{~m}, 3 \mathrm{H}) ; 8.44$ $(\mathrm{d}, J=8.0 \mathrm{~Hz}, 2 \mathrm{H}) ; 8.59$ (s, 1H); $8.98(\mathrm{~s}, 1 \mathrm{H}) ; 9.14(\mathrm{~s}, 1 \mathrm{H}) ; 9.17(\mathrm{~s}, 1 \mathrm{H}) ; 10.03(\mathrm{bs}, 1 \mathrm{H})$. ${ }^{13}$ C NMR (DMF, $\left.100 \mathrm{MHz}\right) \delta 11.8$ (q); 14.5 (q); 18.9 (q); 19.2 (q); 26.8 (d); 29.4 (t); 32.4 (d); $39.4(\mathrm{~d}) ; 58.1(\mathrm{~d}) ; 58.2(\mathrm{q}) ; 60.1(\mathrm{~d}) ; 68.1(\mathrm{t}) ; 68.3(\mathrm{t}) ; 70.3(\mathrm{t}) ; 70.4(\mathrm{t}) ; 70.5(\mathrm{t}) ; 71.9$ (t); $121.6(\mathrm{~d}) ; 127.3$ (s); 127.9 (2d); 128.4 (s); 128.7 (s); 128.8 (2d); 129.4 (s); 130.3 (s); 130.4 (d); 136.5 (s); 139.8 (d); 140.7 (d); 140.8 (d); 142.2 (s); 152.8 (s); 155.8 (s); 158.1 (s); 158.5 (s); 159.6 (s); 160.7 (s); 171.0 (s); 171.6 (s); 171.9 (s). MS (ES) m/z 904 (M + $\left.\mathrm{NH}_{4}, 40\right), 726$ (100), 316 (8), 288 (38). HRMS m/z calcd. for $\mathrm{C}_{42} \mathrm{H}_{47} \mathrm{~N}_{8} \mathrm{O}_{12} \mathrm{~S} 887.3029(\mathrm{M}$ $+\mathrm{H})$ found 887.3037 .

Peptide-heterocycle (3d) The alcohol $3(50 \mathrm{mg}, 0.068 \mathrm{mmol})$ was dissolved in dry $\mathrm{CH}_{2} \mathrm{Cl}_{2}(7 \mathrm{~mL})$ and Boc-L-Arg-(Alloc) $)_{2}-\mathrm{OH}(120 \mathrm{mg}, 0.27 \mathrm{mmol})$, EDC.HCl (52 mg, $0.27 \mathrm{mmol}$ ), DMAP (7 $\mathrm{mg}, 0.57 \mathrm{mmol}$ ) was added drop-wise. The resulting solution was stirred for $31 \mathrm{~h}$ at room temperature, washed with $\mathrm{NaHCO}_{3}$ and $\mathrm{NH}_{4} \mathrm{Cl}$, dried, and 
concentrated. The final product was purified by flash chromatography on silica Bondesil C8 using $\mathrm{H}_{2} \mathrm{O}(0.04 \%$ TFA) and $\mathrm{MeCN}(0.04 \%$ TFA) as eluents (gradient: $0 \%$ to $50 \%)$ to afford 3d $(15.9 \mathrm{mg}, 16 \%)$ as a yellow solid. $[\alpha]_{\mathrm{D}}-11.6(c 0.82, \mathrm{DMSO}) .{ }^{1} \mathrm{H}$ NMR (DMSO, $400 \mathrm{MHz}) \delta$ 0.82-0.94 (m, 9H); $0.99(\mathrm{~d}, J=6.8 \mathrm{~Hz}, 3 \mathrm{H}) ; 1.07-1.17(\mathrm{~m}, 2 \mathrm{H}) ;$ $1.25(\mathrm{~s}, 9 \mathrm{H}) ; 1.35-1.37(\mathrm{~m}, 2 \mathrm{H}) ; 1.57-1.64(\mathrm{~m}, 2 \mathrm{H}) ; 1.73-1.78(\mathrm{~m}, 1 \mathrm{H}) ; 2.01-2.11(\mathrm{~m}$, $1 \mathrm{H}) ; 3.09-3.16(\mathrm{~m}, 2 \mathrm{H}) ; 3.57-3.65(\mathrm{~m}, 1 \mathrm{H}) ; 3.79-3.91(\mathrm{~m}, 3 \mathrm{H})$; 4.47-4.51 (m, 2H); 4.62$4.70(\mathrm{~m}, 3 \mathrm{H}) ; 4.75-4.79(\mathrm{~m}, 1 \mathrm{H}) ; 5.12-5.40(\mathrm{~m}, 4 \mathrm{H}) ; 5.87-5.99(\mathrm{~m}, 2 \mathrm{H}) ; 7.08(\mathrm{bs}, 1 \mathrm{H})$; 7.17 (bs, 1H); 7.30 (bs, 1H); 7.48-7.59 (m, 3H); 8.30-8.33 (m, 2H); 8.51 (s, 1H); 8.53 (s, $1 \mathrm{H}) ; 8.79(\mathrm{bs}, 1 \mathrm{H}) ; 8.98(\mathrm{~s}, 1 \mathrm{H}) ; 9.11(\mathrm{~s}, 1 \mathrm{H}) ; 9.12(\mathrm{~s}, 1 \mathrm{H}) ; 9.98$ (bs, $1 \mathrm{H}) .{ }^{13} \mathrm{C} \mathrm{NMR}$ (DMSO, $100 \mathrm{MHz}) \delta 12.3$ (q); 14.2 (q); 17.9 (q); 18.5 (q); 19.0 (q); 22.4 (d); 26.9 (t); $28.1(\mathrm{t}) ; 28.9(\mathrm{t}) ; 31.9(\mathrm{~d}) ; 41.7(\mathrm{t}) ; 53.4(2 \mathrm{~d}) ; 56.9(\mathrm{~d}) ; 58.1(\mathrm{~d}) ; 65.1(\mathrm{t}) ; 67.0(\mathrm{t}) ; 69.7(\mathrm{t}) ;$ $78.1(\mathrm{~s}) ; 117.1(\mathrm{~s}) ; 117.2(\mathrm{t}) ; 118.3(\mathrm{t}) ; 121.2(\mathrm{~d}) ; 126.4(\mathrm{~s}) ; 127.2(\mathrm{~s}) ; 127.5(\mathrm{~s}) ; 127.8(\mathrm{~s}) ;$ 128.6 (2d); 129.1 (s); 129.6 (2d); 129.7 (s); 130.7 (d); 131.8 (d); 133.5 (s); 133.6 (d); 135.6 (s); 139.5 (d); 140.4 (d); 141.4 (d); 150.4 (s); 152.1 (s); 154.7 (s); 157.4 (s); 157.5 (s); 158.9 (s); 160.0 (s); 170.2 (s); 170.7 (s); 170.9 (s); 173.8 (s). MS (MALDI-TOF) m/z $1189(\mathrm{M}+\mathrm{K}), 1173(\mathrm{M}+\mathrm{Na}, 15), 1151(\mathrm{M}, 10) . \mathrm{HRMS} \mathrm{m} / \mathrm{z}$ calcd. for $\mathrm{C}_{54} \mathrm{H}_{63} \mathrm{~N}_{12} \mathrm{O}_{15} \mathrm{~S}$ $1151.4295(\mathrm{M}+\mathrm{H})$ found 1151.4251 .

Peptide-heterocycle (3e) The $O$-deprotected product (74 mg, $0.101 \mathrm{mmol}$ ) was dissolved in dry $\mathrm{CH}_{2} \mathrm{Cl}_{2}(10 \mathrm{~mL})$. Boc-L-Arg-(Boc) $)_{2}-\mathrm{OH}$ (193 mg, $\left.0.41 \mathrm{mmol}\right)$, EDC.HCl (78 mg, $0.41 \mathrm{mmol})$, and DMAP (12.4 $\mathrm{mg}, 0.102 \mathrm{mmol})$ were then added drop-wise. The resulting solution was stirred for $15 \mathrm{~h}$ at room temperature, washed with $\mathrm{NaHCO}_{3}$ and $\mathrm{NH}_{4} \mathrm{Cl}$, dried and concentrated. The final product was purified by flash chromatography on silica Bondesil $\mathrm{C} 8$ using $\mathrm{H}_{2} \mathrm{O}(0.04 \%$ TFA) and $\mathrm{MeCN}(0.04 \%$ TFA) as eluents 
(gradient: $0 \%$ to $50 \%)$ to give $\mathbf{3 e}(19 \mathrm{mg}, 17 \%)$ as a white solid. $[\alpha]_{\mathrm{D}}-19.4(c 0.12$, DMSO). ${ }^{1} \mathrm{H}$ NMR (DMSO, $\left.400 \mathrm{MHz}\right) \delta$ 0.83-0.95 (m, 12H); 1.09-1.18 (m, 2H); 1.23 (s, $9 \mathrm{H}) ; 1.36(\mathrm{~s}, 9 \mathrm{H}) ; 1.43(\mathrm{~s}, 9 \mathrm{H}) ; 1.45-1.52(\mathrm{~m}, 4 \mathrm{H}) ; 1.60-1.68(\mathrm{~m}, 1 \mathrm{H}) ; 1.96-2.03(\mathrm{~m}, 1 \mathrm{H})$; 3.95-4.04 (m, 1H); 4.11-4.18 (m, 2H); 4.39-4.48 (m, 2H); 4.63-4.69 (m, 1H); 5.63-5.70 (m, 1H); 7.14-7.28 (m, 2H); 7.50-7.75 (m, 3H); 8.17 (bs, 1H); 8.24 (bs, 1H); 8.39-8.41 $(\mathrm{m}, 2 \mathrm{H}) ; 8.55(\mathrm{~s}, 1 \mathrm{H}) ; 8.72$ (bs, 1H); $8.96(\mathrm{~s}, 1 \mathrm{H}) ; 9.09$ (s, 1H); $9.14(\mathrm{~s}, 1 \mathrm{H}) ; 10.7$ (bs, 1H). ${ }^{13} \mathrm{C}$ NMR (DMSO, $\left.100 \mathrm{MHz}\right) \delta 12.4$ (q); 14.5 (q); 19.5 (q); 18.4 (q); $24.6(\mathrm{~d}) ; 28.0$ (q); $28.1(\mathrm{t}) ; 28.3(\mathrm{t}) ; 28.4(\mathrm{q}) ; 28.7(\mathrm{q}) ; 29.4(\mathrm{t}) ; 31.2(\mathrm{~d}) ; 46.8(\mathrm{~d}) ; 53.7(\mathrm{~d}) ; 56.0(\mathrm{~d}) ; 60.2$ (t); $64.6(t) ; 122.4$ (d); 128.4 (2d); 129.3 (2d); 131.0 (d); 140.2 (d); 141.1 (d); 141.4 (d). MS (ES) m/z $1185(\mathrm{M}+2 \mathrm{H}, 60), 1184(\mathrm{M}+\mathrm{H}, 100)$. HRMS m/z calcd. for $\mathrm{C}_{51} \mathrm{H}_{63} \mathrm{~N}_{12} \mathrm{O}_{13} \mathrm{~S}$ ( $\left.\mathrm{M}-\mathrm{Boc}\right) 1083.4352$ found 1083.4351.

Peptide-heterocycle (3f) A solution of $3 e(5 \mathrm{mg}, 4.2 \mu \mathrm{mol})$ in $\mathrm{TFA}-\mathrm{CH}_{2} \mathrm{Cl}_{2}(25: 75,1$ $\mathrm{mL}$ ) was stirred at room temperature for $2 \mathrm{~h}$. The TFA was removed, and the product was used without purification. $[\alpha]_{\mathrm{D}}-40.1$ ( $c$ 0.23, DMSO). ${ }^{1} \mathrm{H}$ NMR (DMSO, $\left.500 \mathrm{MHz}\right) \delta$ 0.83-0.98 (m, 12H); 1.07-1.18 (m, 2H); 1.41-1.76 (m, 5H); 2.03-2.08 (m, 1H); 3.57-3.64 $(\mathrm{m}, 1 \mathrm{H}) ; 4.0-4.04(\mathrm{~m}, 1 \mathrm{H}) ; 4.08-4.18(\mathrm{~m}, 3 \mathrm{H}) ; 4.49-4.56(\mathrm{~m}, 2 \mathrm{H}) ; 4.65-4.68(\mathrm{~m}, 1 \mathrm{H})$; 5.69-5.73 (m, 1H); 7.51-7.62 (m, 7H); $8.20(\mathrm{~d}, J=5.0 \mathrm{~Hz}, 1 \mathrm{H}) ; 8.39-8.41(\mathrm{~m}, 2 \mathrm{H}) ; 8.56$ $(\mathrm{s}, 1 \mathrm{H}) ; 8.71(\mathrm{~d}, J=8.0 \mathrm{~Hz}, 1 \mathrm{H}) ; 8.80(\mathrm{~d}, J=9.0 \mathrm{~Hz}, 1 \mathrm{H}) ; 8.99(\mathrm{~s}, 1 \mathrm{H}) ; 9.10(\mathrm{~s}, 1 \mathrm{H}) ; 9.14$ (s, 1H). ${ }^{13} \mathrm{C}$ NMR (DMSO, $\left.125 \mathrm{MHz}\right) \delta 12.5$ (q); $14.4(\mathrm{q}) ; 19.5(\mathrm{q}) ; 19.7$ (q); $25.0(\mathrm{t}) ;$ $25.1(\mathrm{t}) ; 26.0(\mathrm{t}) ; 26.8(\mathrm{~d}) ; 30.4(\mathrm{~d}) ; 46.9(\mathrm{~d}) ; 56.2(\mathrm{~d}) ; 58.4(\mathrm{~d}) ; 60.3(\mathrm{t}) ; 65.2(\mathrm{t}) ; 70.4(\mathrm{~d})$ 122.3 (d); 128.4 (2d); 129.3 (2d); 131.0 (d); 139.6 (d); 140.9 (d); 141.0 (d). MS (ES) m/z 883 (M, 100). HRMS m/z calcd. for $\mathrm{C}_{41} \mathrm{H}_{47} \mathrm{~N}_{12} \mathrm{O}_{9} \mathrm{~S} 883.3304$ found 883.3317. 
Peptide-heterocycle (9b) Reaction $(20 \mathrm{~h})$ of the free acid 7a $(816 \mathrm{mg}, 1.28 \mathrm{mmol})$ and $\mathbf{8 b}(500 \mathrm{mg}, 1.54 \mathrm{mmol})$ using the general procedure for amide formation gave $\mathbf{9 b}(1.14$ g, 94\%) as a solid. An analytical sample was purified by column chromatography (4:1 to 2:3 hexane-EtOAc) to afford $9 \mathbf{b}$ as a yellow solid, m.p. $\left(\mathrm{CHCl}_{3}\right) 143-145^{\circ} \mathrm{C} .[\alpha]_{\mathrm{D}}+1.4(c$ 0.42, $\left.\mathrm{CHCl}_{3}\right) .{ }^{1} \mathrm{H}$ NMR $\left(\mathrm{CDCl}_{3}, 400 \mathrm{MHz}\right) \delta$ 0.91-1.02 (m, 12H); 1.07 (s, 9H); 1.19-1.29 $(\mathrm{m}, 1 \mathrm{H}) ; 1.48-1.58(\mathrm{~m}, 1 \mathrm{H}) ; 2.07-2.15(\mathrm{~m}, 1 \mathrm{H}) ; 2.20-2.27(\mathrm{~m}, 1 \mathrm{H}) ; 2.58(\mathrm{~s}, 3 \mathrm{H}) ; 3.37(\mathrm{~s}$, $6 \mathrm{H}) ; 3.67-3.73(\mathrm{~m}, 1 \mathrm{H}) ; 3.76-3.80(\mathrm{~m}, 1 \mathrm{H}) ; 3.89(\mathrm{~s}, 2 \mathrm{H}) ; 4.46-4.50(\mathrm{~m}, 1 \mathrm{H}) ; 4.58-4.63$ $(\mathrm{m}, 1 \mathrm{H}) ; 5.24-5.37(\mathrm{~m}, 1 \mathrm{H}) ; 6.70(\mathrm{~d}, J=8.4 \mathrm{~Hz}, 1 \mathrm{H}) ; 7.17(\mathrm{bs}, 1 \mathrm{H}) ; 7.38-7.46(\mathrm{~m}, 4 \mathrm{H})$; $7.80(\mathrm{~d}, J=8.4 \mathrm{~Hz}, 1 \mathrm{H}) ; 8.24-8.30(\mathrm{~m}, 2 \mathrm{H}) ; 8.36(\mathrm{~s}, 1 \mathrm{H}) ; 8.37(\mathrm{~s}, 1 \mathrm{H}) ; 8.47(\mathrm{bs}, 1 \mathrm{H}) .{ }^{13} \mathrm{C}$ $\operatorname{NMR}\left(\mathrm{CDCl}_{3}, 100 \mathrm{MHz}\right) \delta 11.6(\mathrm{q}) ; 11.7$ (q); 14.8 (q); 17.7 (q); 19.3 (q); 26.3 (t); 27.2 (q); 30.9 (d); 31.7 (t); 37.2 (d); 48.4 (d); 50.2 (2q); 57.4 (d); 58.3 (d); 62.2 (t); 73.9 (s); 99.3 (s); 124.3 (s); 126.5 (s); 128.3 (2d); 128.5 (2d); 129.6 (s); 130.2 (d); 140.0 (d); 141.2 (s); 142.6 (s); 143.0 (d); 151.3 (s); 151.7 (s); 153.0 (s); 155.8 (s); 161.3 (s); 161.4 (s); 161.6 (s); 170.9 (s); 171.2 (s); 188.3 (s). MS (MALDI-TOF) $965\left(\mathrm{MBr}^{81}+\mathrm{Na}, 100\right), 963$ $\left(\mathrm{MBr}^{79}+\mathrm{Na}, 85\right)$. HRMS m/z calcd. for $\mathrm{C}_{42} \mathrm{H}_{54}{ }^{79} \mathrm{BrN}_{8} \mathrm{O}_{10} \mathrm{~S} 941.2861$ and 943.2850 found 941.2867 and 943.2853.

Peptide-heterocycle (9c) Reaction $(20 \mathrm{~h})$ of the free acid $7 \mathbf{b}(1 \mathrm{~g}, 1.54 \mathrm{mmol})$ and the $N$ deprotected 8a $(573 \mathrm{mg}, 1.84 \mathrm{mmol})$ using the general procedure for amide formation gave 9c $(1.38 \mathrm{~g}, 95 \%)$ as a yellow solid. An analytical sample was purified by column chromatography (1:1 to 2:3 hexane-EtOAc) to give 9c as a yellow solid, m.p. $\left(\mathrm{CHCl}_{3}\right)$ $116-118{ }^{\circ} \mathrm{C} .[\alpha]_{\mathrm{D}}+2.3\left(c 0.61, \mathrm{CHCl}_{3}\right) .{ }^{1} \mathrm{H} \mathrm{NMR}\left(\mathrm{CDCl}_{3}, 400 \mathrm{MHz}\right) \delta 0.88-0.98(\mathrm{~m}, 9 \mathrm{H})$; $1.01(\mathrm{~d}, J=6.8 \mathrm{~Hz}, 3 \mathrm{H}) ; 1.06(\mathrm{~s}, 9 \mathrm{H}) ; 1.18-1.31(\mathrm{~m}, 1 \mathrm{H}) ; 1.46-1.61(\mathrm{~m}, 1 \mathrm{H}) ; 2.05-2.16$ $(\mathrm{m}, 1 \mathrm{H}) ; 2.19-2.27(\mathrm{~m}, 1 \mathrm{H}) ; 2.78(\mathrm{~s}, 3 \mathrm{H}) ; 3.36(\mathrm{~s}, 6 \mathrm{H}) ; 3.67-3.75(\mathrm{~m}, 1 \mathrm{H}) ; 3.77-3.81(\mathrm{~m}$, 
1H); $3.87(\mathrm{~s}, 2 \mathrm{H}) ; 4.45-4.66(\mathrm{~m}, 2 \mathrm{H}) ; 5.32-5.42(\mathrm{~m}, 1 \mathrm{H}) ; 6.79-6.88(\mathrm{~m}, 1 \mathrm{H}) ; 7.36-7.46$ $(\mathrm{m}, 3 \mathrm{H}) ; 7.78-7.89(\mathrm{~m}, 2 \mathrm{H}) ; 8.07$ (s, 1H); 8.12-8.17 (m, 1H); 8.24-8.29 (m, 2H); 8.36 (s, 1H); 8.51 (bs, 1H). ${ }^{13} \mathrm{C} \mathrm{NMR}\left(\mathrm{CDCl}_{3}, 100 \mathrm{MHz}\right) \delta 11.6$ (q); 12.1 (q); 14.7 (q); 17.7 (q); $19.3(\mathrm{q}) ; 26.4(\mathrm{t}) ; 27.2(\mathrm{q}) ; 30.8(\mathrm{~d}) ; 31.8(\mathrm{t}) ; 37.2(\mathrm{~d}) ; 48.5(\mathrm{~d}) ; 50.2(2 \mathrm{q}) ; 57.4(\mathrm{~d}) ; 58.3$ (d); $62.4(\mathrm{t}) ; 73.9$ (s); 99.2 (s); 125.0 (s); 126.7 (s); 128.2 (2d); 128.3 (2d); 129.4 (s); 130.0 (d); 139.4 (d); 141.4 (s); 143.3 (d); 152.0 (s); 152.4 (s); 152.8 (s); 154.6 (s); 158.8 (s); 161.4 (s); 164.1 (s); 171.0 (s); 171.3 (s); 173.6 (s); 188.0 (s). MS (MALDI-TOF) 965 $\left(\mathrm{MBr}^{81}+\mathrm{Na}, 100\right), 963\left(\mathrm{MBr}^{79}+\mathrm{Na}, 80\right) . \mathrm{HRMS} \mathrm{m} / \mathrm{z}$ calcd. for $\mathrm{C}_{42} \mathrm{H}_{54}{ }^{79} \mathrm{BrN}_{8} \mathrm{O}_{10} \mathrm{~S}$ 941.2861 found 941.2870.

Peptide-heterocycle (9d) Reaction $(20 \mathrm{~h})$ of the free acid $7 \mathbf{b}(763 \mathrm{mg}, 1.17 \mathrm{mmol})$ and $\mathbf{8 b}(458 \mathrm{mg}, 1.41 \mathrm{mmol})$ using the general procedure for amide formation gave 9d as a solid (1.05 g, 94\%). An analytical sample was purified by column chromatography (4:1 to $2: 3$ hexane-EtOAc) to give $9 \mathbf{d}$ as a yellow solid, m.p. $\left(\mathrm{CHCl}_{3}\right) 147-149{ }^{\circ} \mathrm{C} .[\alpha]_{\mathrm{D}}+3.5$ (c $\left.0.76, \mathrm{CHCl}_{3}\right) .{ }^{1} \mathrm{H} \mathrm{NMR}\left(\mathrm{CDCl}_{3}, 400 \mathrm{MHz}\right) \delta 0.91-1.03(\mathrm{~m}, 12 \mathrm{H}) ; 1.09(\mathrm{~s}, 9 \mathrm{H}) ; 1.22-$ $1.31(\mathrm{~m}, 1 \mathrm{H}) ; 1.47-1.58(\mathrm{~m}, 1 \mathrm{H}) ; 2.08-2.17(\mathrm{~m}, 1 \mathrm{H}) ; 2.21-2.30(\mathrm{~m}, 1 \mathrm{H}) ; 2.58(\mathrm{~s}, 3 \mathrm{H})$; $2.79(\mathrm{~s}, 3 \mathrm{H}) ; 3.37(\mathrm{~s}, 6 \mathrm{H}) ; 3.68-3.73(\mathrm{~m}, 1 \mathrm{H}) ; 3.77-3.80(\mathrm{~m}, 1 \mathrm{H}) ; 3.88(\mathrm{~s}, 2 \mathrm{H}) ; 4.43-4.54$ $(\mathrm{m}, 1 \mathrm{H}) ; 4.57-4.63(\mathrm{~m}, 1 \mathrm{H}) ; 5.24-5.37(\mathrm{~m}, 1 \mathrm{H}) ; 6.69(\mathrm{~d}, J=8.4 \mathrm{~Hz}, 1 \mathrm{H}) ; 7.10(\mathrm{bs}, 1 \mathrm{H})$; 7.38-7.46 (m, 3H); 7.78-7.83 (m, 2H); 8.25-8.30 (m, 2H); 8.37 (s, 1H); $8.44(\mathrm{bs}, 1 \mathrm{H}) .{ }^{13} \mathrm{C}$ $\operatorname{NMR}\left(\mathrm{CDCl}_{3}, 100 \mathrm{MHz}\right) \delta 11.6(\mathrm{q}) ; 11.7$ (q); 12.1 (q); 14.7 (q); 17.7 (q); 19.3 (q); 26.4 (t); 27.3 (q); 30.9 (d); 31.8 (t); 37.1 (d); 48.4 (d); 50.3 (2q); 57.4 (d); 58.3 (d); 62.2 (t); 73.9 (s); 99.2 (s); 124.4 (s); 125.0 (s); 126.7 (s); 128.3 (2d); 128.4 (2d); 129.4 (s); 130.0 (d); 141.2 (s); 142.9 (d); 151.2 (s); 152.0 (s); 152.5 (s); 152.8 (s); 155.8 (s); 158.8 (s); 161.5 (s); 170.8 (s); 171.0 (s); 171.2 (s); 188.4 (s). MS (MALDI-TOF) 979 (MBr ${ }^{81}+\mathrm{Na}$, 
100), $977\left(\mathrm{MBr}^{79}+\mathrm{Na}, 85\right)$. HRMS m/z calcd. for $\mathrm{C}_{43} \mathrm{H}_{56}{ }^{79} \mathrm{BrN}_{8} \mathrm{O}_{10} \mathrm{~S} 955.3018$ and to $\mathrm{C}_{43} \mathrm{H}_{56}{ }^{81} \mathrm{BrN}_{8} \mathrm{O}_{10} \mathrm{~S} 957.3007$ found 955.3028 and 957.3009.

Peptide-heterocycle (9e) Reaction $(20 \mathrm{~h})$ of the free acid $7 \mathbf{a}(1.37 \mathrm{~g}, 2.15 \mathrm{mmol})$ and $\mathbf{8 c}$ (580 $\mathrm{mg}, 2.59 \mathrm{mmol})$ using the general procedure for amide formation gave $9 \mathrm{e}(1.78 \mathrm{~g}$, $98 \%)$ as a solid. An analytical sample was purified by column chromatography (1:1 to $2: 3$ hexane-EtOAc) to give 9e as a solid m.p. $\left(\mathrm{CHCl}_{3}\right) 132-134{ }^{\circ} \mathrm{C} .[\alpha]_{\mathrm{D}}+22.4(c \quad 0.49$, $\left.\mathrm{CHCl}_{3}\right) .{ }^{1} \mathrm{H} \mathrm{NMR}\left(\mathrm{CDCl}_{3}, 400 \mathrm{MHz}\right) \delta$ 0.89-1.07 (m, 12H); 1.22-1.31 (m, 1H); 1.51-1.61 $(\mathrm{m}, 1 \mathrm{H}) ; 2.05-2.18(\mathrm{~m}, 1 \mathrm{H}) ; 2.21-2.45(\mathrm{~m}, 1 \mathrm{H}) ; 3.37(\mathrm{~s}, 6 \mathrm{H}) ; 3.79-3.86(\mathrm{~m}, 1 \mathrm{H}) ; 3.89(\mathrm{~s}$, 2H); 4.29-4.84 (m, 3H); 6.77-6.95 (m, 1H); 7.35-7.44 (m, 3H); 7.74-7.85 (m, 2H); 8.04 (s, 1H); 8.09-8.12 (m, 1H); 8.17-8.25 (m, 2H); $8.31(\mathrm{~s}, 1 \mathrm{H}) ; 8.36(\mathrm{~s}, 1 \mathrm{H}) ; 8.49$ (bs, 1H). ${ }^{13} \mathrm{C} \mathrm{NMR}\left(\mathrm{CDCl}_{3}, 100 \mathrm{MHz}\right) \delta 11.3(\mathrm{q}) ; 15.0$ (q); 17.5 (q); 19.5 (q); $26.0(\mathrm{t}) ; 29.8$ (d); $31.6(\mathrm{t}) ; 36.4(\mathrm{t}) ; 36.6(\mathrm{~d}) ; 50.3(2 \mathrm{q}) ; 58.4(\mathrm{~d}) ; 58.6(\mathrm{~d}) ; 99.3(\mathrm{~s}) ; 126.5(\mathrm{~s}) ; 128.2(2 \mathrm{~d})$; 128.4 (2d); 129.4 (s); 130.1 (s); 130.3 (d); 139.6 (d); 140.1 (d); 141.4 (s); 143.3 (d); 151.8 (s); $153.0(\mathrm{~s}) ; 154.5$ (s); $161.4(\mathrm{~s}) ; 161.7$ (s); 161.9 (s); 162.6 (s); 171.5 (s); 171.8 (s); 188.1 (s). MS (MALDI-TOF) $865\left(\mathrm{MBr}^{81}+\mathrm{Na}, 100\right), 863\left(\mathrm{MBr}^{79}+\mathrm{Na}, 85\right) . \mathrm{HRMS} \mathrm{m} / \mathrm{z}$ calcd. for $\mathrm{C}_{36} \mathrm{H}_{42}{ }^{79} \mathrm{BrN}_{8} \mathrm{O}_{9} \mathrm{~S} 841.1973$ found 841.1968 .

\section{Cell lines and Culture}

Human-derived established cell lines used in this study were purchased from ATCC (American Type Culture Collection): A-549, human lung carcinoma (ATCC \# CCL-185), HT-29, human colorectal adenocarcinoma (ATCC \# HTB-38), and MDA-MB 231, human breast adenocarcinoma (ATCC \# HTB-26).

All cell lines are maintained in DMEM (Dulbecco's Modified Eagle's Medium) culture medium supplemented with 10\% FBS (Fetal bovine serum), and 100 Units/mL penicillin 
and streptomycin at $37^{\circ} \mathrm{C}$ and $5 \% \mathrm{CO}_{2}$. Triplicate cultures were incubated for 72 hours in the presence or absence of test compounds (at 10 concentrations typically ranging from 10 to $0.0026 \mu \mathrm{g} / \mathrm{mL})$.

A colorimetric assay using sulforhodamine B (SRB) has been adapted for a quantitative measurement of cell growth and viability, following a previously described method. ${ }^{16}$ Cells are plated in 96 -well microtiter plates at a density of $5 \times 10^{3} /$ well and incubated for 24 hours. One plate from each different cell line is fixed and stained, and used for $\mathrm{Tz}$ reference (see next paragraph). After that, cells are treated with vehicle alone (control) or compounds at the concentrations indicated. Treated cells are further incubated for 72 hours and cytotoxic evaluation performed by colorimetric analysis.

In brief, cells are washed twice with phosphate buffered saline (PBS), fixed for $15 \mathrm{~min}$ in $1 \%$ glutaraldehyde solution, rinsed twice in PBS, and stained in $0.4 \%$ SRB solution for $30 \mathrm{~min}$ at room temperature. Cells are then rinsed several times in $1 \%$ acetic acid solution and air-dried. SRB was then extracted in $10 \mathrm{mM}$ trizma base solution and the absorbance measured at $490 \mathrm{~nm}$. Cell survival is expressed as percentage of control cell growth.

Dose-response curves are performed by using the NCI algorithm: ${ }^{17} \mathrm{Tz}=$ number of control cells at time $t_{0}, C=$ number of control cells at time $t$, and $T=$ number of treated cells at time t.

If $\mathrm{Tz}<\mathrm{T}<\mathrm{C}$ (Growth inhibition) then: $100 *([\mathrm{~T}-\mathrm{Tz}] /[\mathrm{C}-\mathrm{Tz}])$

If $\mathrm{T}<\mathrm{Tz}$ (Net cell killing) then: $100 *([\mathrm{~T}-\mathrm{Tz}] / \mathrm{Tz})$

After dose-curve generation, results are experessed as $\mathrm{GI}_{50}$, compound concentration that causes $50 \%$ cell growth inhibition, as compare to control cultures.

\section{Cell cycle analysis}


Cell cycle analysis was performed by propidium iodide staining to determine DNA content. Subconfluent cells treated with either $35 \mathrm{nM} 1$ or $172 \mathrm{nM} 2$ or $135 \mathrm{nM} 3 \mathbf{c}$ for 12 $\mathrm{h}$, were trypsinyzed, collected by centrifugation, resuspended in PBS, and then fixed in $70 \%$ ethanol. The fixed cells were incubated with $5 \mathrm{mg} / \mathrm{mL}$ propidium iodide (Sigma), $0.1 \mathrm{mg} / \mathrm{mL}$ RNase A (Sigma), and $0.1 \%$ triton $\mathrm{X}-100$ for $15 \mathrm{~min}$ at $37{ }^{\circ} \mathrm{C}$ and analyzed with a Beckman Coulter Epics XL using the $488 \mathrm{~nm}$ line of argon laser. The cell cycle profile was analyzed using Cell Quest software.

\section{Apoptosis assay}

The methodology used is based on fluorochrome inhibitors of caspases (FLICA; CaspaTag In situ Caspase Detection Kits, Chemicon International, USA and Canada). The inhibitors are cell permeable and non-cytotoxic. Once inside the cell, the inhibitor covalently binds to the active caspase. This kit uses a carboxyfluorescein-labeled fluoromethyl ketone peptide inhibitor of caspase-3 (FAM-DEVD-FMK), which fluoresces green. When added to a group of cells, the FAM-DEVD-FMK probe enters each cell and covalently binds to a reactive cysteine residue in the large subunit of the active caspase heterodimer, thereby inhibiting further enzymatic activity. ${ }^{18}$

Subconfluent cells cultured on coverslips were treated with either $35 \mathrm{nM} 1$ or $172 \mathrm{nM} 2$ or $135 \mathrm{nM} \mathrm{3c}$ for $24 \mathrm{~h}$. After treatment, 30X FLICA reagent was added at 1:15 dilution in culture medium and incubated for $1 \mathrm{~h}$ at $37^{\circ} \mathrm{C}$. The cells were washed with PBS and analyzed using a Leica TCS SP2 laser scanning confocal spectral microscope (Leica Microsystems Heidelberg GmbH, Mannheim, Germany) with a band pass filter excitation at $490 \mathrm{~nm}$ and emission at $520 \mathrm{~nm}$ to view the green fluorescence of caspase-positive 
cells. The green fluorescence signal was a direct measure of the amount of active caspase- $3 / 7$ present in the cell at the time the reagent was added.

\section{Acknowledgments}

This study was partially supported by CICYT (BQU 2006-03794), Generalitat de Catalunya, and the Barcelona Science Park. We gratefully acknowledge PharmaMar S.L. for performing the preliminary biological tests, and the Networking Centre on Bioengineering, Biomaterials and Nanomedicine (CIBER-BBN). We also thank Dr. L. M. Cañedo for her contributions to compound purification. D.H. thanks the Ministerio de Educación y Ciencia for a predoctoral fellowship.

Supporting Information Available: Experimental details, characterization of synthetized compounds and a table of HPLC purities of final compounds. This material is available free of charge via the Internet at htt://pubs.acs.org

\section{REFERENCES AND NOTES}

(1) Yeung, K.; Paterson, I. Actin-Binding Marine Macrolides: Total Synthesis and Biological Importance. Angew. Chem. Int. Ed. 2002, 41, 4632-4653.

(2) Recent revisions about the chemistry and properties can be found in: (a) Roy, R. S.; Gehring, A. M.; Milne, J. C.; Belshaw P. J.; Walsh C. T. Thiazole and oxazole peptides: biosynthesis and molecular machinery. Nat. Prod. Rep. 1999, 16, 249263. (b) Yeh, V. S. C. Recent advances in the total syntheses of oxazole-containing natural products. Tetrahedron 2004, 60, 11995-12042. (c) Riego, E.; Hernández, D.; Albericio, F.; Álvarez, M. Directly linked polyazoles: Important moieties in natural products. Synthesis 2005, 1907-1922. (d) Jin, Z. Imidazole, oxazole and thiazole alkaloids. Nat. Prod. Rep. 2006, 23, 464-496. 
(3) Nagatsu, A.; Kajitani, H.; Sakakibara, J. Muscoride A: A new oxazole peptide alkaloid from freshwater cyanobacterium Nostoc muscorum. Tetrahedron Lett. 1995, 36, 4097-4100.

(4) Kehraus, S.; König, G. M.; Wright, A. D. Leucamide A: A New Cytotoxic Heptapeptide from the Australian Sponge Leucetta microraphis. J. Org. Chem. 2002, 67, 4989-4992.

(5) (a) Shin-ya, K.; Wierzba, K.; Matsuo, K.; Ohtani, T.; Yamada, Y.; Furihata, K.; Hayakawa, Y.; Seto, H. Telomestatin, a Novel Telomerase Inhibitor from Streptomyces anulatus. J. Am. Chem. Soc. 2001, 123, 1262-1263. (b) Doi, T.; Yoshida, M.; Shin-ya, K.; Takahashi T. Total Synthesis of $(R)$-Telomestatin. Org. Lett. 2006, 8, 4165-4167.

(6) Lindquist, N.; Fenical, W.; Van Duyne, G. D.; Clardy, J. Isolation and structure determination of diazonamides $\mathrm{A}$ and $\mathrm{B}$, unusual cytotoxic metabolites from the marine ascidian Diazona chinensis. J. Am. Chem. Soc. 1991, 113, 2303-2304.

(7) (a) IB-01211 was isolated from the marine microorganism strain ES7-008 by Romero, F.; Malet, L.; Cañedo, L, M.; Cuevas, C.; Reyes, J. New cytotoxic depsipeptides. WO 2005/000880 A2, 2005. (b) The same structure was proposed for mechercharmycin A, isolated from a marine-derived Thermoactinomices sp., by: Kanoh, K.; Matsuo,Y.; Adachi, K.; Imagawa, H.; Nishizawa, M.; Shizuri, Y. Mechercharmycins A and B, Cytotoxic Substances from Marine-derived Thermoactinomyces sp. YM3-251 J. Antibiot. 2005, 58, 289-292.

(8) (a) Hernández, D.; Vilar, G.; Riego, E.; Cañedo, L. M.; Cuevas, C.; Albericio, F.; Álvarez, M. Synthesis of IB-01211, a cyclic peptide containing 2,4-concatenated 
thia- and oxazoles, via Hantzsch macrocyclization. Org. Lett. 2007, 9, 809-811. (b) Hernández, D.; Riego, E.; Francesch, A.; Cuevas, C.; Albericio, F.; Álvarez, M. Preparation of penta-azole containing cyclopeptides: challenges in macrocyclization. Tetrahedron 2007, 63, 9862-9870.

(9) Sohda, K-y.; Nagai, K.; Yamori, T.; Suzuki, K-i.; Tanaka, A. YM-216391, a novel cytotoxic cyclic peptide from Streptomyces nobilis. J. Antibiot. 2005, 58, 27-31.

(10) Hydrolysis of the methyl ester was performed using $\mathrm{LiOH}$ in aqueous THF and $\mathrm{MeOH}$ as it is detailed in the experimental section.

(11) This conditions for the thiazole Hantzsch synthesis afforded an easier purification crude material than the obtained before, see ref 8 .

(12) Using the standard conditions of $\mathrm{Pd}\left(\mathrm{PPh}_{3}\right)_{4}, \mathrm{PhSiH}_{3}$, in $\mathrm{CH}_{2} \mathrm{Cl}_{2}$.

(13) $\mathrm{IC}_{50}$ for YM-216391 in HeLa S3 is $14 \mathrm{nM}$. Described in Sanada, K; Takeba-yashi, Y.; Nagai, K.; Hiramoto, M. New antitumor compound. Jpn. Kokai Tokkyo Koho JP11180997-A, 1999; Chem. Abstr. 1999, 131, 101307j.

(14) Hernández, D.; Riego, E.; Albericio, F.; Álvarez, M. Eur. J. Org. Chem. 2008, in press.

(15) Ekert, P. G.; Silke, J.; Vaux, D. L. Caspase inhibitors Synthesis of natural product derivatives containing 2,4-concatenated oxazoles. Cell Death and Differ. 1999, 6, 1081-1086.

(16) Skehan, P.; Storeng, R.; Scudiero, D.; Monks, A.; McMahon, J.; Vistica, D.; Waren, J. T.; Bokesch, H.; Kenney, S.; Boyd, M. R. New colorimetric cytotoxicity assay for anticancer drug screening. J. Natl. Cancer Inst., 1990, 82, 1107-1112. 
(17) Boyd, M. R.; Paull, K. D. Some practical considerations and applications of the National Cancer Institute in vitro anticancer drug discovery screen. Drug Dev. Res. 1995, 34, 91-104.

(18) Rotonda, J.; Nicholson, D. W.; Fazil, K. M.; Gallart, Y. G.; Labelle. M.; Peterson, E. P.; Rasper, D. M.; Ruel, R.; Vaillancourt, J. P.; Thornberry. N. A.; Becker, J. W. The three-dimensional structure of apopain/CPP32, a key mediator of apoptosis Nature Struct. Biol. 1996, 3, 619-625.

\section{Table of Contents Graphic}

\section{Synthesis and Antitumor Activity of Mechercharmycin A Analogs}

D. Hernández, M. Altuna, C. Cuevas, R. Aligué, F. Albericio,, M. Álvarez

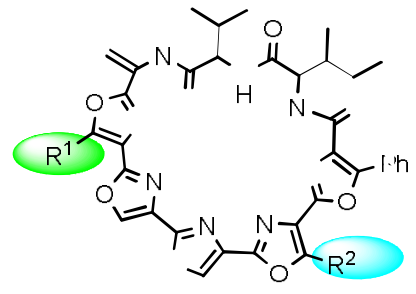

$R^{1}, R^{2}=H, M e$

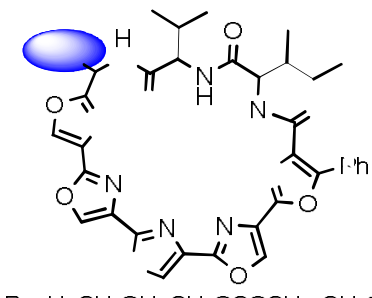

$\mathrm{R}=\mathrm{H}, \mathrm{CH}_{2} \mathrm{OH}, \mathrm{CH}_{2} \mathrm{OCOCH}_{3}, \mathrm{CH}_{2} \mathrm{OArg}$

$\mathrm{CH}_{2} \mathrm{OCOCH}_{2}\left(\mathrm{OCH}_{2} \mathrm{CH}_{2}\right)_{n} \mathrm{OCH}_{3}$, 